\title{
HACIA UNA HISTORIA DE LA RECEPCIÓN DE CELESTINA: 1499-1822
}

\author{
Joseph T. Snow \\ Michigan State University
}

Es ésta la primicia de un proyecto que, inevitablemente, me va a significar largas horas de trabajo a lo largo de varios años. Es con especial placer que dedico esta primera cosecha para honrar la estimable labor en el campo celestinesco de Louise Fothergill-Payne. Rosa Garrido detalla bien cuáles han sido las aportaciones de Louise al hispanismo en general, $y$ a la celestinesca en particular, en su apreciación al comienzo de este festnummer. Bien quisiera recordar yo una de ellas en especial, el artículo que mandó Louise a esta revista en 1984, "La cambiante faz de Celestina," en el cual sigue las huellas e impacto de la Tragicomedia en la inspiración y motivos constituyentes de obras españolas a finales del siglo XVI. Sigue la pauta de lo que es, en su quintaesencia, el fenómeno de la "celestinesca," ese impacto de una obra maestra que no sólo define su época sino que se apodera fuertemente de la imaginación creadora (y transformadora) de las generaciones posteriores. Es totalmente apropiado que esta revista ahora homenajea a esta estudiosa que en estos momentos esta redondeando la labor del equipo que va preparando la largamente sonada y soñada edición de otro importante hito en la "celestinesca" del siglo XVI, la anónima Celestina comentada.

La meta que tengo para este proyecto es - deo volente -la de producir una obra de consulta sobre la celestinesca para los años que enmarcan el trayecto de la historia de la recepción de la obra desde su aparición en 1499 hasta la salida de la primera edición 'moderna,' la de León Amarita (Madrid 1822). ${ }^{1}$ Esta nueva obra se entroncará en su día con otro proyecto bibliográfico que comenzará en este año 1822 y que nos llevará al siglo XXI, una considerable expansión de la bibliografía mía publicada hace ya más de

${ }^{1}$ Pero, como se verá, esta edición aparece 'corregida' en 1835 y, por esta y otras razones, el límite ad quem de esa recopilación hay que tomarlo como aproximado siempre. 
una década con la Hispanic Seminary of Medieval Studies, ${ }^{2}$ y adicionada con los suplementos bibliográficos que aparecen en esta revista.

La organización de esto nuevo proyecto será sencilla: Esta entrega es nada más un esbozo. Como pretende ser algún día una historia completa de lectores y lecturas de Celestina - en los sentidos más amplios de estas palabras - es lógico que siga una línea cronológica. Iré publicando entregas hasta que haya oportunidad de sacar una primera versión provisional, la cual se irá perfeccionando con siempre nuevos (y más completos) datos y citas. Daré el año (a veces tendrá que ser aproximado), las referencias bibliográficas $y$, hasta el punto que sea útil, citas directas del texto y resúmenes de los materiales a encontrarse en cada entrada. Si conviene, también cito de ediciones modernas para que el usuario pueda consultar los textos de que disponga o tenga más a mano. Las siglas BL y BNM indican provenencia de la fuente manejada de o la British Library o la Biblioteca Nacional de Madrid.

Para llamar la atención a otras posibles fuentes, el lector nada más tiene que dirigirse a mí por carta a las señas editoriales (ver la contraportada de esta revista), por Fax (517/432-3844) o por correo electrónico (snow@pilot.msu.edu). Pueden utilizarse también el WebPage, que se encuentra en: http://polyglot.cal.msu.edu/celestinesca.html

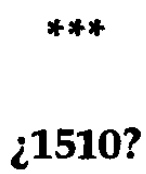

Un romance que comienza:

Un caso muy sennalado quiero, señores, contar Como se iba Calisto - para la caza cazar, En huertas de Melibea - una garza vido estar Echado la había el falcón - que la oviese a tomar, El falcón con gran codicia - no se cura de tornar Saltó dentro el buen Calisto - para habello de buscar, Vido estar a Melibea - en el medio de un rosal, Ella está cogiendo rosas - y su doncella arrayán ...

\footnotetext{
${ }^{2}$ J.T. Snow, 'Celestina' by Fernando de Rojas: An Annotated Bibliography of World Interest, 1930-1985. Madison WI: HSMS, 1985.
} 
Se puede encontrar el texto completo en M. Menéndez Pelayo, Antología de poetas líricos castellanos, ed. E. Sánchez Reyes, vol. 25 de la Edición Nacional de las Obras Completas de ... (Madrid: CSIC, 1945), pp. 135-143.

\section{1}

"Como muestra de bibliotecas particulares, ofrecemos el índice de la que perteneció al honrado regidor compostelano Francisco Treviño, fallecido al año 1511: 'Otro que se dize los cinco libros de Séneca ... coronica troyana ... y otro de correllas y braçayda ... otro de Celestina ... otro de vision deletable ....'"

Citado de Antonio López Ferreiro, Galicia en el último tercio del siglo XV, tomo II (= Biblioteca Gallega, vol. 45), (La Coruña: A. A. Martínez, 1897, 2a. ed. corregida y aumentada), págs. 239-240.

\section{3}

Pedro Manuel Ximénez de Urrea. Cancionero de las obras de Pedro Manuel de Urrea. Logroño: Arnao Guillen de Brocar, 1513. Fols xliv-xlix = "Egloga de la Tragicomedia $\mathrm{d}$ Calisto y Melibea, de prosa trobada en metro, por don Pedro de Urrea, dirigida a la condesa de Aranda su madre." Coplas octosilábicas (abba), se versifican partes del primer auto de la Tragicomedia.

1514

Pedro Manuel Ximénez de Urrea. Penitencia de amor compuesto por don .... Burgos: Fadrique Alemán de Basilea, 1514. Con un grabado previamente visto en la CCM. Prosa, razonamientos y cartas con unas octavas de arte menor.

Como albacea del testamento de Juan Picart, Salvador Cerdo (presbítero de la Seo de Zaragoza) hizo un inventario fechado el 17 de septiembre de 1517, que incluye en fol. $162^{\mathrm{v}}$ :

Una arte de canto llano.

Hun libro de Celestina.

Hun brebario romano....

Citado de Arch Hist. P. Zaragoza, Protocolo de Iñigo de Exea, fols $160^{v}$ $162^{\mathrm{v}}$, en Documentos para el estudio de la historia del libro en Zaragoza entre 
1501 y 1521, comp. Manuel José Pedraza Gracia, Zaragoza: Centro de Documentación Bibliográfica Aragonesa, 1993, p. 273.

Giovanni Nevizzano. Sylva Nuptialis. Asti, 1518 (cito de la ed. de Lugduni: Antonium de Harsy, 1572. BNM 3/24296.

(1) "...imò Exiguo pulchram ducit solertia vitam. gloss. in verb. solertem in clemen $\mathbf{j}$ de offic. deleg. \& econtrà, Richeza mal disposta a pouerta se acosta. Salic in l. vbi adhuc, col. ij $\mathrm{C}$. de jure dot. facit Celestina actu iiij incip adeso circa medium vbi de auaritia diuitum acto xij post medium ..." (IV.7, pág. 260).

(2) "Et Celestina semper incedebant cum mantello beguinarum, \& longa filzia pater nostrorum (...) Et ab audiente duas missas omni mane, \& à iurante per conscientiam meam, prout semper faciebat Celestina. \& omnino corrumpunt bonos mores colloquia mala" (IV.63, pág. 309).

(3) "...Et quomodo bibendum \& inedendum ebrietati latè Pet. de Lesnaudiere in tract. de Doctorib. iiij parte q. lxij vbi per quatuor chart. \& multum debemus naturae deistis duobus liquoribus, vino scilicet \& oleo. Lancel. in 1 . ij (paragraph sign) j. ff. fi cert. peta. plura tradit Celestina in laudem vini. Actuum IX incip. porta. chart. ij. de ebrietate Seneca ad Lucillunt (...)" (IV.96, pág. 343).

(4) "... \& fie tardiores in emissione feminis, saepius concurrut anticipat eam. \& fie facilius generant senes, quam iuuenes, licet senectus multa habeat mala, de quibus Celestina Act. iiij (...)" (IV.108, pág. 353).

(5) "... facit Celestina circa fin vj actus" (IV.117, pág. 359; sobre la conservación de la belleza con 'arte').

(6) "... latè Celestina in princ. secundi actus. incip. fratelli. \& dato annua por anno: id est nunc, non in fine anni ..." (IV.130, pág. 369; el tema es la liberalidad).

(7) "...Plura hinc inde potes colligere in Ouidio de tristibus libr. iij. sub rubr. ad amicum, vt magnorum virorum consuetudinem fugiat. Celestina Actu. ix. incipi. porta. post medium Claude omnia vnico versu medicorum: Esuriant, sitiant, sigelent, laborent qui 
reumata curant. Sed on petas alta si pati nescieris: quoniam fauor Curiae infinitos extollit \& si tu ad alta perscalam Curiae scandere volueris praemitte quod Hadr. Papa ..." (IV.155, pág. 397).

(8) "... \& malesie quae vt placeret marito suo tantum te restrinxit, quod nec ipse nec alius potuit alius cam cognoscere. de qua arte vide in Aenea muliebri. c.ij. char. $X \&$ in Tragicomoedia Celestinae latissime" (II.38, págs. 147-148).

(9) "praeterea plura requiruntur vt mulier possit dici pulchra, vide (...) quid Calistus in Celestina cap. j" (II, 93, pág. 182).

(10) "Praeterea nulla adeò turpis quae amarorem non inueniar, saltem turpem. Imò quandoque adsunt mariti odientes pulchram vxorem \& ardentes amore alicuius meretricis deformis \& cum illisas deformitas eis obiicitur; respondent, eam non vides oculis meis. Frater Bernard j. parte Rosarij serm. xxiij litera e (...) sed Sempronius apud Celestinam dicebat in e.eum oculis scilicet speculi ignei, quod paruum facit videri magnum (...)" (II.96, pág. 184).

(11) "Et tu Hispane Sempronium apud Celestinam cap. j" (I.162, pág. $80)$.

(12) "Et dicit ipse in praedicamento relationis, quòd dubitare de singulis non est inutile refert. gl. in liij C. de sum. Trin. Bart. in processorum (para sign) \& antea. Barbat. ib iiij cons. xl. elementissimum col. j. Hadrianus vj Papa noster in Quodlibetis q. vj col. pen \& Sempronius apud Celestinam c. j quòd sol reuerberatus fortius calefacit \& clauus repercussus fortius stringit" (I.6, pág. 3).

\section{9}

En la repartición de los bienes de Domingo Paniza (labrador, vecino de Zaragoza), había:

Item, un libro de Calixto, 1 sueldo

Citado de Arch. Hist. P. Zaragoza, Protocolo de Pedro Serrano, 1519, ff. 53-61, en Documentos para el estudio de la historia del libro en Zaragoza entre 1501 y 1521, comp. Manuel José Pedraza Gracia, Zaragoza: Centro de Documentación Bibliográfica Aragonesa, 1993, p. 292. 
Carajicomedia (impresa por primera vez en el Cancionero de obras de burlas provocantes a risa, novena parte del Cancionero general de Hernando del Castillo, Valencia: Juan de Vinao, 22 febrero de 1519).

Estando en estado impotente, el autor menciona en la copla XX:

Luego resurgen muy malas hedores, $y$ viene una vieja muy seca y enxuta, en darme remedio muy sabia y astuta, que luego potencia me muestra favores (...)

$Y$ sigue (en prosa):

Quien esta vieja sea, el autor, por vergonçoso, no lo declara; pero es de saber qu'ella se llamó en tiempos antigos María de Vellasco; ya por discurso de sus maldades pereció aquel nombre. Solamente agora se conosce y llama, hablando con reverencia, la Buyça, que cierto es en la villa de Valladolid tan temeroso de oyr como el de Celestina; mas es cierto que la desdichada de Celestina se llevó la fama, y ésta goza el provecho de tal nombre (162).

Luego, sigue en la copla XLVII:

Vi tres putas, conviene a saber, Gudínez, Miranda, la Páez en persona,

(...)

pues tres oficios cada cual resalta, alcahueterías, y hoder, que no falta, y hechizos crueles, que usan hazer.

Su comentario se inicia así:

Si las maldades d'estas tres putas oviesse d'escrevir, ni papel bastaría ni mano lo podría sofrir. Pareció bastar que diga algo, siquiera para consolación de algunos devotos que esta obra leerán. Es de saber que esta primera de llama Ynés Gudínez, que es la más maldita puta vieja que 'ab inicio' nació. D'esta es público que agora en sus postrimeros días, sellando su vida, cometió el más vil crimen que Celestina nunca hizo, y fue que vendió una hija suya a un frayle por ciertos dineros (182). 
Citas de la edición de la Carajicomedia de Carlos Varo, Madrid: Playor, 1981. También se encuentran en la ed. de Frank Domínguez del Cancionero de obras de burlas provocantes a risa, Valencia: HispanófilaAlbatros, 1978, en las págs. 146-147 y 158, respectivamente.

\section{1}

Gil Vicente. Auto das Ciganas (ed. facsimil de la Copilaçao de todalas obras de ..., Leonor Carvallao Buesca, ed., Lisboa: Imp. NacionalCasa de Moeda, 1983), vol II, págs 488-495. BNM 4-226006.

Giralda: Dad acá mayo florido eça mano, Melibea.

Por bien, ceñura, te cea buen marido, buen marido. (494)

\section{¿1521?}

Hernán de Yanguas. "Triumphos de Locura, nueuamente compuestos de ...." Valencia: Juana de Joffre, ¿1521?.

Bajo la rúbrica 'Triumpho del veer', escribe:
Alguno tiene muger tan desaliñada y fea que nadie la quiere veer ni para sí la dessea por su torpe parescer. Y si, a dicha, su marido es de los que doy partido no ay vez de quantas la vea que muy por cierto no crea que tiene a la reyna dido o a la gentil Melibea y que su par no a nascido.

Citado de Cuatro obras del bachiller Hernán López de Yanguas. Siglo XVI. El ayre de la almena, textos literarios rarísimos, III, Cieza: 'la fonte que mana y corre ...", 1960. BNM VC 4211-18.

Francisco de Moraes escribe: "Em sexta feira de Endoenças do anno de 1521 vi no mosteiro de Sam Francisco en bragança um Diogo 
Lopes, ferreiro (...) estar ante o Sacramento en roda de mulheres lendo por Celestina, a parece-me que era no auto que falla do Centurio."

Citado de Antonio Caetano de Sousa, História Genealógica da Casa Real Portuguesa, Lisboa, 1738, Provas. II, p. 448.

Juan Luis Vives. De institutione feminae christianae / La formación de la mujer cristiana. Amberes, 1523.

Deberían igualmente (las autoridades) ocuparse de los libros pestíferos, como son, en España, Amadis, Esplandián, Florisando, Tirant lo Blanch y Tristán, cuyas locuras nunca tienen final y de los que a diario salen títulos nuevos; la alcahueta Celestina, madre de necedades y carcel de amores; en Francia ... (67)

Citado de la traducción por Joaquín Beltrán Serra, Colección J. L. Vives 4A, València: Ajuntament de València, 1994.

Lope Ortiz de Stúniga. "Farsa en coplas sobre de comedia de Calisto y Melibea." Incipit:

Hi de san y qué floresta

$Y$ qué floridos pradales

Qué compaña ...

Citado del Registrum, no. 15.139 de don Fernando Colón.

1525

En el proceso inquisitorial, 7 junio 1525, Alvaro de Montalbán (suegro de Rojas) dice tener una hija, "Leonor Alvarez, mujer del bachiller Rojas, que compuso a Melibea, vecino de Talavera."

Juan de Maldonado. Hispaniola. Valladolid: N. Tierry, 1525. Obra dramática, con final feliz, con muchas semejanzas con la TCM (Trilo, la Nodriza, es la figura celestinesca). Ver la edición, traducción con introducción y notas de $\mathbf{M}^{\mathbf{a}}$ Ángeles Durán Ramas (Colección Erasmo, Textos Bilingües, Barcelona: Bosch, 1983), esp. págs. 37-38 de la introd. 
Francisco Delicado, Lozana andaluza el qual Retrato demuestra lo que en Roma passaua y contiene munchas mas cosas que la Celestina.

De la Dedicatoria:

"Sabiendo yo que vuestra señoría toma placer cuando oye hablar de cosas en amor (...) y porque en vuestros tiempos podéis gozar de persona que para sí y para sus contemporáneos, que en su tiempo florido fueron en esta alma cibdad, con ingenio mirabile y arte muy sagaz, diligencia grande, vergüenza y conciencia (...) ha administrado ella [Lozana] y un su pretérito criado [Rampín] (...) el arte de aquella muger que fue en Salamanca, en tiempos de Celestino segundo." (79)

del Mamotreto 36:

"Monseñor, ésta es Carcel de Amor, aquí idolatró Calisto, aquí no se estima Melibea, aquí poco vale Celestina." (190)

del Mamotreto 47:

Lozana: Quiero que me leáis, vos que tenéis gracia, las Coplas de Fajardo [= Carajicomedia] y la Comedia Tinelaria y a Celestina, que huelgo de oír estas cosas muncho.

Silvano: ¿Tiénela vuestra merced en casa?

Lozana: Señor, velda aquí, mas no me la leen a mi modo, como haréis vos. (223)

Citado de la edición de Giovanni Allegra, Temas de España 159, Sección de Clásicos, Madrid: Taurus, 1985.

\section{9}

Fray Antonio de Guevara. Relox de Príncipes. Valladolid, 1529.

"Con mucha razón y con gran ocasión son de loar los príncipes de España, los coraçones de España, los ayres de España, las aguas de España y la fertilidad de España, mas junto con esto, maldigo y reniego de muchos vulgares libros que ay en España, los quales como unos reloxes quebrados merescían echarse en el fuego para ser otra vez hundidos (...) porque ya $\tan$ sin vergüença y $\tan$ sin conciencia se componen oy libros de amores 
del mundo (...) Compassion es de ver los días y las noches que consumen en leer libros vanos, es a saber: a Amadís, a Primaleón, a Duarte, a Lucrecia, a Calixto, con la doctrina de los grandes osaré dezir que no passan tiempo, sino que pierden el tiempo, porque alli no deprenden cómo se han de apartar de los vicios, sino qué primores ternán para ser más viciosos." (38-39)

Citado de la edición y estudio de Emilio Blanco, Escritores Franciscanos Españoles 1, Conferencia de Ministros Provinciales de España: ABL Editores, 1994.

Henrici Cornelii Agrippa. De incertidumbre \& Vanitate Scientiarum \& Artium. Amberes: Joan Grapheus, 1530. BNM U/6582.

"Post istos vero non infimum inter lenones locum, sibi vendicant Rhetores, fraudulentarum blanditiarum, \& persuasionum artifices illa acB lenarum foelicissima cui propitia est dea Suadela: Superiorem tamen istis locum possident Historici, illi praecipue qui amatorias illas Historias contextuerunt Lancelloti, Tristanii, Eurealis, Pelegrini, Calisti \& similium in quibus fornicationi \& adulteriis a teneris annis puellae instituuntur \& assuescunt necque cero machina quaeuis ad oppognandum cum matronarum pudicitiam tum virginum ac viduarum castimoniam validiot q. lectio lascuiare Historiae (...)." (89v)

"Et apud Horatium Canidia, apud Apuleium Pamphilae maleficae suos amatores astingunt, \& in Calisti tragicomoedia Celestina lena Meliboeam puellam accendit. Accedunt iis etiam veneficia \& philtra amatoria pocula ..." (90v-91r).

Juan Luis Vives. Disciplina.

"En este punto [amores ilícitos] fue incomparablemente más cuerdo el que escribió en nuestro vulgar castellano la tragicomedia de la Celestina, pues a los amores avanzados hasta un límite ilícito y a aquellos deleites pecaminosos, dioles una amarguísima ejemplaridad con el trágico fin y la caída mortal de los amantes, y a las muertes violentas de la vieja alcahueta y de 
los rufianes que intervinieron en ese escarmentador celestineo." (416)

Citado de la traducción y ed. de Lorenzo Riber, Las disciplinas Parte I, lib. ii, cap. v (Valencia: Aguilar/Generalitat Valenciana, 1992).

Feliciano de Silva. Segunda Celestina. Medina del Campo: Pedro Torans, 1534.

De la Carta proemial:

" ... esta segunda comedia de Celestina escriví." (106)

De la $22^{\mathrm{a}}$ cena:

Palana: Como si no supiésemos aquí quién es Celestina, á cabo de ser coronada tres veces por alcahueta. $(347$, cf. TCM, acto II)

Citado de la ed. de Consolación Baranda, Letras Hispánicas 284, Madrid: Cátedra, 1988.

Clement Marot. Du coq à l'asne. A Lyon Jamet, 1535.

Or ça, le livre de Flammette, Formosum Pastor, Celestine, Tout cela est bonne doctrine Et n'y a rien de deffendu.

Citado de la edición de Les oeuvres de Clement Marot (La Haie: chez Adrien Moetjens, 1714), pág. 170.

\section{h. 1535}

Juan de Valdés. Diálogo de la lengua. En tres MSS del siglo XVI; publicado por primera vez, anónimo, en Orígenes de la lengua espafiola compuestos por varios autores recogidos por Don Gregorio Mayans y Siscar, tomo I, Madrid: Juan de Zúñiga, 1737. 
1. Valdés: De la lengua latina querria tomar estos vocablos: ambición, ecepción, dócil, superstición, obieto. Del qual vocablo usó bien el autor de Celestina: La vista a quien obiecto no se pone: y digo que lo usó bien porque quiriendo dezir aquella sentencia, no hallara vocablo castellano con que dezirla (...). (141)

\section{Otro excerpto:}

Pacheco: Abasta harto; por lo mío, llamadlo como quisiéredes.

Marcio: ¿Qué dezís de Celestina? Pues vos mucho su amigo soléis ser. Valdés: De Celestina, me contenta el ingenio del autor que la començó, y no tanto el del que la acabó; el juizio de todos dos me satisfaze muchho porque sprimieron a mi ver muy bien y con mucha destreza las naturales condiciones de las personas que introduxeron en su tragicomedia, guardando el decoro dellas desde el principio hasta la fin.

Marcio: ¿Quáles personas os parecen que stán mejor esprimidas?

Valdés: La de Celestina está a mi ver perfetíssima en todo quanto pertenece a una fina alcahueta. y las de Sempronio y Pármeno; la de Calisto no stá mal, y la de Melibea pudiera estar mejor.

Marcio: ¿Adónde?

Valdés: Adonde se dexa muy presto vencer, no solamente a amar, pero a gozar del deshonesto fruto del amor.

Marcio: Tenéis razón.

Pacheco: Dexáos agora, por vuestra vida, de hazer anotomía de la pobre Celestina; basta que la hizieron los moços de Calisto. Dezidnos qué os parece del estilo.

Valdés: El estilo, en la verdad, va muy bien acomodado a las personas que hablan. Es sverdad que peca en dos cosas, las quales fácilmente se podrían remediar, y quien las remediasse, le haría gran honra. La una es en el aontonar de vocablos algunas vezes tan fuera de propósito como Magnificat a maitines; la otra es en que pone algunos vocablos tan latinos que no s'entienden en el castellano, y en partes adonde podría poner propios castellanos, que los ay. Corregidas estas dos cosas en Celestina, soy de opinión que ningún libro ay escrito en castellano donde la lengua sté más natural, más propia no más elegante.

Marcio: ¿Por qué vos no tomáis un poco de trabajo y hazéis esso?

Valdés: Demás estava. (174-176)

Citado de la edición de Juan M. Lope Blanch, Clásicos Castalia 11, Madrid: Castalia, 1985. 
Feliciano de Silva. Segunda comedia de la famosa Celestina en la qual se trata de la resurrection de la dicha Celestina y de los amores de Felides y Polandria, corregida y enmendada por Domingo de Gaztelú. Venecia: Stephano da Sabio, 1536.

De la 'Dedicatoria':

"... e imperho ragionevole cos mi(e) aparso anzi cognosciuto ho (essere il debito mio grande) che facendo io imprimere la ingeniosa e docta resurrectione di Celestina: cosa nova e delectevole (...)."

Feliciano de Silva. Segunda Celestina... Salamanca: Pedro de Castro, 1536.

Gaspar Gómez de Toledo. Tercera Parte de la tragicomedia de Celestina. Medina del Campo, 1536.

1539

Fray Antonio de Guevara. Aviso de privados y doctrina de cortesanos. Citado de la edición publicada en Amberes: M. Nucio, 1546, "Argumento," fol. $\mathbf{x v}^{\mathrm{v}}$.

" $\mathrm{O}$ cuan desuiada esta oy la republica de lo que aqui escreuimos y aconsejamos: pues vemos que ya no se occupan los hombres sino en leer libros que es affrenta nombrarlos: como son Amadis de Gaula, Tristan de Leonis, Primaleon, Carcel de amor y a Celestina: a los quales todos y a otros muchos con ellos se deuría mandar por justicia que no se imprimiessen ni menos se vendiessen; porque su doctrina incita la sensualidad a peccar y relaxa el espiritu a bien biuir."

Gaspar Gómez de Toledo. Tercera Parte de la tragicomedia de Celestina ( $2^{\mathrm{a}}$ ed.) Toledo: Hernando de Santa Catalina, 1539.

Joao de Barros. Cartinha. Lisboa: Luis Rodrigues, 1539. Contiene en las págs. 50-61 su «Dialogo em lovvor a nossa lingvagem».

"A linguágem portuguesa que tenha ésta gravidade, nam pérde a força pera declarár, mover, deleitár e exortár a párte a que se enclina, seja em qual género de escritura. Verdáde é ser em si tam honésta e cásta, que paréce nam consintir em si ua tál óbra como Çelestina, que Gil Viçente (...) nunca se atreveu a 
introduzir um Çenturio português, porque, como ô nam consente a naçám, assi ò nam sófre a linguágem." (55)

Más accesible es la edición facsimilar de esta obra, presentada por $\mathrm{M}^{\mathrm{a}}$ Leonor Carvalhao Buesco, Lisboa: Univ. de Lisboa - Fac. de Letras, 1971, donde lo citado se encuentra en la pág. 166.

\section{0}

Juan Cromberger, hijo, deja un inventario de sus libros en la Nueva España-México (selección):

446 Amadis de Gaula

325 Celestina

194 Flores y Blancaflor

800 Troyanas ...

Citado de Irving A. Leonard. Books of the Brave (1949)\{with a new Introduction by Rolena Adorno\} (Berkeley: U California P, 1992), p. 98.

Fernando de Rojas. Celestina. Lisboa: Luis Rodrigues, 1540 (en castellano).

Juan Sedeño. Síguese la tragicomedia de Calisto y Melibea, nueuamente trobada y sacada de prosa en metro castellano, por .... Salamanca: Pedro de Castro, 1540. 114 págs, con un 'Prólogo al lector'.

Jorge Ferreira de Vasconcellos. Comedia Eufrosina. Coimbra: Ioan de Barreyra, 1540.

\section{1}

Blasco de Garay. "Cartas en refranes castellanas," en Proceso de cartas de amores y otras obras, Toledo, 1541. BNM U-8319.

Del Prólogo a las 'Cartas':

"De manera que no me aure desmandado mucho, en juntar tal suerte de deleyte: $y$ el principal prouecho que aqui hazer pretendo, no tanto à los muy bien doctrinados, quanto à los que no suelen leer, sino a Celestina o cosas semejantes." (5-6)

Presenta (págs. 101-126) el Diálogo entre el amor y vn Cauallero viejo de Rodrigo de Cota y, en pág. 101, dice que compuso Cota, 
entre otras cosas, "el primer auto de Celestina, que algunos falsamente atribuyen a Iuan de Mena."

Miguel de Salinas. Rhetorica en lengua castellana. Alcalá de Henares: Juan de Brocar, 1541. BNM R/452.

"Síguese vna forma para poner por exercicio las reglas de la rhetorica passada" (...) [Ejemplo] "De las comedias. Si quisiesse Parmeno quitar de la voluntad a Calisto el amor que tiene a Melibea: o Jusquino a Floribundo el amor que tiene a Calamita." (fol. 79v)

"Es muy bueno leer siempre en autores que escriuieron bien el castellano, como es Torres Naharro, Hernando del Pulgar, y no es menos buena la comedia de Calisto y Melibea y otros." (fol. $\left.86^{\mathrm{v}}\right)$

Sancho de Muñón. Tragicomedia de Lisandro y Roselia llamada Elicia y por otro nombre quarta obra y tercera Celestina. Salamanca: Juan de Junta, 1542.

Oligides: - Esta dexo dos sobrinas, Areusa y Elicia. Areusa llevola Centurio al partido de Valencia; quedò Elicia ya vieja y de días, la cual viendo que los arrugaban su rostro, y que su casa no se frequentaba como solía de galanes, ni menos sus amigos la visitaban, determinó, pues con su cuerpo no podía ganar de comer, ganallo con el pico y tomar el oficio de su tía.

Eubulo: - ... yo oí que su tía le dexó por heredera en el testamento de una camarilla que tenía llena de alambiques, de redomillas (...) para mejor exercitarse el arte de hechicería, que ayuda mucho, según dicen, para ser afamada alcahueta; ya creo que es bien diestra, astuta y sagaz en estas artes liberales.

13 sept. 1542. Un inventario de las cosas vendidas por Juan Jofre a Joan Navarro, librero, por 200 libras (A. P. V. protocolos de Ausias Metellier, sig. 1542). Incluye:

Un juego de las historias de melosina.

Un juego de las historias de celestina.

Un juego de las historias de roberto... 
Citado de Philippe Berger, Libro y lectura en la Valencia del Renacimiento, vol. 2 (Valencia: Inst. Valenciana d'estudis i investigació, 1987), documento F7, pp. 506-508.

Fray Luis de Alarcón, O.S.A. Camino del cielo. Y de la maldad y ceguedad del mundo. Alcalá, 1547.

"Extrema locura es, que siendo de nuestra cosecha tan mal inclinados, se lean libros con que sean los vicios mas avivados (...) Del numero de estos libros son el latino Ovidio y Terencio en algunas obras, y otros tales; en romance, un Amadís o Celestina y otros semejantes."

Edición y prólogo de Angel Custodio Vega, O.S.A., Barcelona: Juan Flors, 1959 (editada a base de la edición de Granada 1550).

Anónimo. Comedia de Sepúlveda. Sevilla, 1547 (MS fechado).

Alarcón: Bien me paresce. Yo voy á escribir, aunque tengo entendido que este muchaçho no hará cosa buena.

Parrado: Cuando él no lo hiciere como queremos, yo conozco una vieja que dará quince y falta à la madre Celestina; que es ladina y sabe más ruindades que cuatro mill diablos (...) y yo haré que tome á su cargo este negocio.

Alarcón: Menos es de fiar desa tal que tiene eso por oficio (...) yo quiero lo que está acordado, é it luego á escribir la carta. (60-61)

Citado de la edición de Emilio Cotarelo y Mori, Madrid: Impta. de la Revista Española, 1901.

Jorge Ferreiro de Vasconcellos. Comedia Vlisippo. $1^{\mathrm{a}}$ ed. 1547. Citas de la $2^{\mathrm{a}}$ ed. Lisboa: Pedro Craesbeek, $1618\left(2^{\mathrm{a}}\right.$ impressao apurada \& correcta de alguns erros da primeira).

Acto 1, escena iv:

Barboda (criado): Nao nego que pode ser que fosse ella menos coàira por ser moça, \& nao sabe inda que tem libre, nem entende as leis de seu fadairo: porem he matinada da 
celestina da may qe sempre anda rangendo com rabugem, \& he tao desaforada que despira os altares. (fol. 41 ${ }^{\mathrm{v}}$ )

Acto 3, escena vi (elogio del vino):

Parasito: ... O que bem cheira, he bom, \& faz proueito: o grosso \& sem cheiro, faz roins huores: o azedo, he vilao roim, $\&$ benzer delle. $O$ vinho claro he sutil, faz vontade de coer (mas pera isto bem posso em escusalo) faz os homens piadosos, \& humildes.

Crisofilo: $\mathrm{E}$ vos dirlhe mais virtudes que a madre Celestina ... (fol. 158)

Acto 4, escena iv (loor de la viuda-alcahueta Costança Dornelas):

Fileno (galán): ... comecei louuala, pedindo lhe perdao (...) que ja via que era tudo mentira quanto me tinhao dito: \& que folgaua conhecerla (...) Que vos direi? A madre Celestina nao soube tanta theorica: nem se pode contar o terço do que huma destas diz desque começa. (fol. $197^{r}$ )

Sebastián Fernández. Tragedia Policiana. En la qual se tractan los muy desdichados amores de Policiano \& Philomena, executados por industria de la diabólica vieja Claudina, Madre de Pármeno \& maestra de Celestina. Toledo: Diego López, 1547.

Sebastián Fernández. Tragedia Policiana. En la qual se tractan los muy desdichados amores de Policiano \& Philomena, executados por la industria de la diabólica vieja Claudina, madre de Pármeno \& maestra de Celestina. Toledo: Diego López, 1548 ( $2^{\mathrm{a}}$ ed.).

Se incluyen en esta edición unos versos titulados "Luis Hurtado al Lector" de los cuales citamos éstos:

Lector desseoso de claras sentencias

Aquí debuxa la madre Claudina

Debaxo de gracias sabrosa dotrina

Para guardar del mal las conciencias: ... 
Joao de Rodrigues de Castello Branco, Amato Lusitano, Dioscórides, Venecia: Gualterum Scotum, 1553, libro III, en. 99, pág. 1907.

Al hablar de la cola, dice que prefiere á todas la preparada junto al puente - apud pontem paratum non procul à domo Celestinae mulieris famosíssimae et de quale legitur in comedia Calisti et Melibeae. Salamanca, suceso de hacia 1525.

\section{h. 1553}

Juan Arce de Otálora. Coloquio de Palatino y Pinciano, Jornada Sexta, Estancia Octava. [BL Ms Eger 578.]

Palatino: Yo tengo por cierto que aunque Celestina es buen libro y de grandes avisos y sentencias, ha estragado tanto a los letores como aprovechado, y mucho más sus subcedoras, la Feliciana y Muñona y las demás, porque no sé si son tan agudas y graciosas, y sé que son más deshonestaś (...) De mí os digo que si fuesse casado, no consintría en mi casa estos libros prophanos, Amadises, ni Felicianos, ni Celestinas, sino un Flos Sanctorum o un Cartuxano y otros deste xaez, donde se leen y oyen exemplos de Christo Nuestro Señor, y de sus sanctos.

Citado de D. Eisenberg, Romances of Chivalry (Newark, DE: Juan de la Cuesta, 1982), Appendix, pp. 159-166, at pp. 162 y 165.

\section{4}

Alonso de Villegas Selvago, Comedia llamada Selvagia. Toledo: Juan Ferrer, 1554.

Versos acrósticos, de las estrofas 4 y 5 :

Sabemos de Cota que pudo empeçar Obrando su ciencia, la gran Celestina, Labróse por Rojas, su fin con muy fina Ambrosia, que nunca se puede estimar.

Compuso la parte segunda partida, Osando por causa pasar de lo humano, Materia teniendo de Feliciano, En quien elegancia no tiene medida: 
De norte tan claro tomando seguida, Intento guiarme por esta jornada, A ver si mi cimba pequeña caxcada Sabrá por buen puerto donde fué regida. (VIII)

Citado de la edición con prólogo firmado por el Marqués de Fuensanta del Valle y José Sancho Rayón, Colección de Libros Españoles Raros ó Curiosos, V, Madrid: Rivadeneyra, 1873.

Joan Rodríguez Florián. Comedia llamada Florinea. Medina del Campo: Guillermo de Millis, 1554. BNM R-1387.

Comienzan los muchos parecidos celestinescos con el argumento de la primera cena que es como proemio de toda la obra:

"Floriano llega a la ciudad de Belisea y confiesa su amor al camarero y antiguo criado Lydorio, a quien pide remedio de su enfermedad."

Fol. $105^{r-v}$ (Gracilia y Liberia, dos doncellas):

Gracilia: Ya, ya, de oy mas todo te hablo de sanctidades. Y asi lo que veo es, prima, que agora vas harta a missa. Pues quiero que agora nos vamos, con que sepas de mi esto mientras cierro mi puerta, que quando tu viniste a te asentar a este atambor, ya yo debaxo desta vandera era soldado viejo en esta guerra. $Y$ no presumas hurtar hogaça a quien $\tan$ a menudo cueze y amasa. $Y$ así sepas de mi que he passado los textos viejos, y en esta nueva mercaduría soy tratante viejo. Mira que dize vn autentico original, que de cosario a cosario, no ay mas aventura de en las vasijas.

Liberia: A la fe, prima, esse original en el texto de la ley Celestínica esta estampado y así son palabras que dixo la vieja hablando con Areúsa. Y asi el verdadero trasunto del texto no dize como le acotaste sino que de cosario a cosario no se pierden sino los barriles.

Sebastián de Horozco, "Conversión de Inglaterra al Catolicismo. Memoria de las fiestas y alegrías que en Toledo se hizieron por esta razón" (BNM MSS IMP 65). 
"En este tiempo salieron máscaras de moros, judíos, doctores, médicos, deçeplinantes, salvajes, locos, triperos, melcocheros, buñoleros, cornudos, romeros, diablos, correas, porteros de cofradías, caçadores, hermitaños, negros, negras, portugueses, amazonas, ninfas, cardenales, monjas viudas, Çelestina con su cuchillada y su canastilla de olores, lençeras, vizcaynas, reyes, pastores y aun frayles salieron al prinçipio aunque la justicia se lo prohibió, otros muchos disfrazes así a cavallo como a pie."

Citado de la edición de Jack Weiner, Historias toledanas de Sebastián de Horozco (Serie II ${ }^{\mathrm{a}}$ - Vestigios del Pasado, 8; Toledo: Inst. Provincial Investigaciones y Estudios Toledanos/CSIC, 1981), pp. 126-127.

Alonso Martínez de Laguna de los Cameros, Suma de Doctrina cristiana, compuesto por el Bachiller ..., Salamanca: J. de Canova, 1555. Del prólogo:

Y pues no se tiene por contento el que no tiene en su casa cuatro o cinco Celestinas, no se debría contentar el cristiano hasta haber cuantas Artes pudiese servir a Dios.

Gonzalo Fernández de Oviedo y Valdés. Quinquagenas de la Nobleza de Espafta, Primera Parte. Santo Domingo, 1555.

El reflejo celestinesco se ve claramente en esta nota:

De las alcahuetas. Aqui el testo (...) trae a consequençia el ardid de la vieja maldita, e rezadera de las fiestas sin que las guarde (...) son tizones que, como leña vieja, más arde e despierta la verde para que se ençiende (...) $Y$ así una vieja con un poco de vino, e su codiçia de pelar simples (...) quieren [ellas ganar] por descompassar liuianas, e adquirir lo que pueden de ambas partes. Offiçio es tan prejudicial, donde tales terçeras se comportan, e tan dañosas, como todo ombre bien entendido lo comprehenderá: $\mathrm{E}$ aquellos que más [dan] a esas mensageras (...) esos son que primero lo escotan ... por sus personas e bienes $\mathrm{e}$ onrras, $\mathrm{y}$ aun a vezes con las vidas.

Citado de la ed. de Vicente de la Fuente, Madrid: Real Academia Española, 1880, vol. I, págs. 111-112. 
Bonaventure des Perriers. Les contes, ou les Nouvelles Récréations et Joyeux Devis. Lyons, 1558. Citado de la ed. de Amsterdam: Z. Chatelain, 1735.

"Et puis il auoit reduict en mémoire et par escript les ruses plus singulieres que les femmes inventent pour auroir leur plaisir. Il sçauoit les allées \& les venues que font les vielles par les maisons sous ombre de porter du fil de la toile, des ouurages, des petits chiens. Il sçauoit comme les femmes font les malades, comme elles vont en vendages, comme elles s'entrefont faueur souz ombre de parentage, Et auec cela, il auoit leu Bocace et Celestine." (I:188)

\section{9}

Juan de Timoneda. Las tres comedias del facundíssimo Poeta .... Valencia, 1559. BNM R-9557.

De 'El autor a los lectores':

"Quan apazible sea el estilo cómico para leer puesto en prosa, y quán propio para pintar los vicios y las virtudes (amados lectores) bien lo supo el que compuso los amores de Calisto y Melibea, y el otro que hizo la Tebaida. Pero faltauales a estas obras para ser consumadas poderse representar como los que hizo Bartholome de Torres y otros en metro. Considerando yo esto, quise hazer Comedias en prosa, de tal manera que fuessen breves y representables; (...) y hechas, como paresciessen muy bien assi a los representantes como a los auditores, rogaronme muy encarecidamente que las imprimiesse, porque todos gozassen de obras tan sentenciosas, dulces y regocijadas."

h. 1560

Sebastián de Horozco. Cancionero de .... Edición de Jack Weiner, Berne-Frankfurt: Lang, 1975, pág. 62.

Puta vieja embaidora ponçoñosa serpentina, maldita encandiladora heredera y suçesora de la vieja Celestina. Gastaste tu juventud en ser puta cantonera 


\begin{abstract}
y agora en la senetud estando en el ataúd vives de ser cobertera. Sonsacando mil moçuelas $\mathrm{y}$ albergandolas a todas, frayles y moços d'espuelas dando casa, cama y belas para hazer torpes bodas. No ay moço ni despensero que a tu casa no se acorra, cayendo con su dinero; pues guarte del rocadero $\mathrm{y}$ açotes con miel y borra ...
\end{abstract}

Juan Lorenzo Palmireno. Phrases Ciceronis obscuriores in hispanicam linguam conversae a .... Valencia: Petri à Huete, agosto de 1572. BNM $\mathrm{R} / 17450$. Las págs. 22-47 contienen "Hypotyposes clarissimorvm virorvm ad extemporalem dicendi facultatem vtilissime" y de éstos:

5. Mira la hypotyposis del excellente Ioan de Mena, o del Bachiller Rojas de Montaluan (...) "Porque señor te matas? porque señor te congoxas? y tu piensas que es vituperio en las orejas desta, el nombre que le llame? no lo creas: que assi se glorifica en le oyr, como tu quando dizen diestro cauallero es Calisto. Que quieres mas? sino que si vna piedra topa con otra luego suena puta vieja (25-26).

1574

En un interrogatorio llevado a cabo por Ambrosio de Morales, «Relaciones geográficas que los pueblos de Castilla dieron a Felipe II desde 1574 en adelante», el cap. 37 pedía nombres de los ilustres, y Ramírez Orejón, de La Puebla de Montalbán, contestó y se lee: Celestina."

"de la dicha villa fué natural el bachiller Rojas, que compuso a

A. López Pinciano. Philosophia antigua poética, Madrid, 1576. 
-Ay os espero, replicó el Pinciano. ¿Pues por qué las trágicas y cómicas son tan cortas en comparación de las épicas? ¿Por ventura está este negocio de las fábulas en el vso también como las demás cosas?

-No, dixo, Fadrique, no está sino en razón. Y aunque la diera mejor que yo Vgo, quiero agora dezir la mía. Las fábulas trágicas y cómicas bien se pudieran entender tanto como las épicas, quanto al volumen dellas; que aquí esta la Celestina, que es muy larga, y también ley yo otra que dizen La Madre de Parmeno, la qual era mucho más. Pero como estos tales poemas son hechos principalmente para ser representados, siendo largos, no lo pueden ser - representados, digo - y pierden mucho de su sal.

Citado de la edición de Alfredo Carballo Picazo, Biblioteca de antiguos libros hispánicos, Madrid: CSIC - Inst. Miguel Cervantes, 1953, p. 49.

Odet de Turnèbe. Les Contens. Citas de M. Edouard Fournier, Le Théatre Français au XVI et au XViie siècle, París: Laplace, Sánchez et $C^{\text {ie }}$ [1871].

De la introducción de Fournier:

"... elle touche d'assez près par quelques parties á la Celestina, cette grande comédie (...) mais nulle part, ni d'un coté ni de l'autre, l'imitation n'est précise ni directe." (91)

"On trouve de pareilles recettes por le maquillage (...) dans le Courtisane repentie de Du Bellay, la Fidelité de Larivey (Acte II, sc. x), et la comédie espagnole, la Célestine." (nota 5, pág. 105)

\section{0}

Juan de la Cueva. Comedia de El Infamador, en Primera Parte de las Comedias de Ioan de la Cueva dirigidas a Momo. Sevilla: Juan de León, 1580.

De la Primera Jornada, ll. 164-170:

Ortelio (criado): De su casa a la calle iba saliendo con sola su criada Felicina, y dijo así, como me vió, riendo: 
"Bien negoció la nueva Celestina.

No le osé replicar, y ella siguiendo

su vía, sin hablarme más camina

y el camino del río dirigieron,

y yo me vine y ellas dos se fueron."

De la Tercera Jornada, 11. 333-339:

Eliodora: ¿No estuviste agora aquí

con las dos viejas Claudinas?

Felicina: De todo estó inocente. ¿No me hallaste en la cama?

Eliodora: ¡Después de urdida la trama se quiere hacer que no siente!

Felicina: Señora, ¿echas bernaldinas?

Citado de la edición de Clásicos Castellanos 60, Madrid: Espasa-Calpe, $1973\{1924\}$.

Anthony Munday. Second and Third Blast of Retrait from Plays and Theatres. Londres, 1580.

"The nature of these Comedies are, for the most part, after one manner of nature, like the tragical Comedie of Calistus, where the bawdress Scelestina inflamed the maiden Meliboia with her sorceries. De wee not vse in these discourses to counterfeit witchcraft, charmes drinkes \& amorous potions, thereby to drawe the affections of men \& stir them up unto lust (...)."

Citado de Hispanic Review 28 (1960). pág. 310.

\section{2}

Obras de Diversos Recopilados (1582), BNM MS 3924.

De folio $135^{\mathrm{r}}$ :

Çelestina que Dios aya en su vejez que fue tutora de Siluia cierta señora y como patrona y aya amiga y procuradora tomando tinta y papel y llamando al escriuano 
por el termino profano escriuio esta carta en el firmandola de su mano. Glossa

Muchas vezes Siluia mia te rrogare que me creas porque si em bano t'enpleas passara tu lozanía sin que medrada te veas $y$ pues es hecho Romano engañar a una muger si por alguno as de hazer si es diremos de tu mano Siluia, primero as de ber.

De folios $140^{\mathrm{v}}-142^{\mathrm{r}}$ : "Testamento de celestina que pues mallograda la come la tierra. enterralle la boca de fuera."

Incipit: Çelestina cuya fama durara siglos sin cuento sana de su entendimiento y enfermo el cuerpo en la cama ordeno su testamento

No quiso llamar amigos la que se gozo con tantos sino al escriuano Santos que delante tres testigos fue diziendo: sepan quantos ...

Explicit: Dio la postrer boqueada

Çelestina y espiro y su gente la lloro diziendo a la mal lograda que pues mal lograda la come la tierra enterralla la Boca de fuera.

Folio 142v": "Codizillo de çelestina."

Incipit: Estando ya en ?? çelestina de duarte hizo un codicillo aparte despues de su testamento ... 
Explicit: Con esto las mandas cierra

y el codicillo l'otorgo

$y$ en el punto que acabo

se le apalabro la yerva.

1566-1583

Protocolo de Alonso Hernández, Archivo Nacional del Perú, fol. 1419-1422 vuelta.

Anota un acuerdo entre Juan Jiménez del Río y Francisco de la Hoz en la cual éste había de comprar entre otros libros:

"12 celestinas de las mas chicas con flores de oro la meitad y la otra mitad en pergamino...".

1583

Juan Jiménez del Río, librero limeño, incluye a Vives y Rojas en un pedido de mas de 2.000 libros de España (22 de febrero).

\section{5}

Visita de las naos, Septiembre de 1585 a San Juan de Ulúa (México):

Nao San Juan: Libros (...) La Celestina, y otros en romance y los siguientes prohibidos (...).

Citado en Francisco Fernández del Castillo, Libros y libreros en el siglo XVI, $2^{\mathrm{a}}$ ed., México: Fondo de Cultura Económica, 1982, pág. 418.

Luis de Camoes. "Filodemo". En Primeira parte dos autos $e$ Comedias portuguezas, feitas por António Prestes e por Luis de Camoes, e por outros Autores Portuguezes, cujos nomes vao nos principios de suas obras. [Lisboa?]: Andrés Lobato, 1587.

Acto I, ll. 390-399 (habla Vilardo):

Quem havia de cuidar Que dama formosa e bella Saltasse o demonio nella, 
Para a fazer namorar

De quem nao ha igual della?

Que me dizeis a Solina? (Solina es la figura celestinesca)

Como se faz Celestina,

Que por nao lhe haver inveja

Tambem para si deseja

o que o desejo lh'ensina! (91)

Acto II

Filodemo: Como templará el destemplado? (197)

Acto V (Vilardo a Doloroso):

Ja sabeis que esta nossa Solina he tao Celestina, que nao ha quem a traga a nós. (276)

Bernardo González de Bobadilla. Primera parte de las ninphas y pastores del Henares. Alcalá: Juan Gracian, 1587. Libro V, fol. 178v. BNM R-14994.

(Florindo y otros) "... se fueron de conformidad platicando a pasear y a mostrar a Florindo las cosas memorables que ay en la famosa Salamanca, conviene a saber, los insignes teatros (...), los reales y innumerables collegios de doctos y letrados hombres, la cueba cegada donde dizen auerse leydo la nigromancia, la nombrada y poco vistosa torre de Melibea, y la derribada casa de la vieja Celestina, los passatiempos y recreaciones del humilde Tejares (...)."

Jorge Pinto. "Auto de Rodrigo e Mendo" (= Primeira parte dos autos e Comedias portuguezas, feitas por António Prestes y por Luis de Camoes, e por outros autores Portuguezes, cujos nomes vao nos principios de suas obras, fols. $\left.48^{\mathrm{v}}-60^{r}\right)$. Lisboa: Andrés Lobato, 1587.

Rodrigo: Ora em fim Mendo, ficamos amigos de pedra \& cal, \& eu the pormeto que nos lhe façamos hua \& boa, somente porque conheça que muitos sao os que deste mal feridos vao.

Mendo: Se eu isso vejo, Rodrigo, a rassam te dou du mes.

Rodrigo: Eu te vingarey de Ines, pois he malina.

Mendo: He a mesma Celestina de verdade.

Rodrigo: Por te fazer a vontade eu lhe armarey a esparrela porem, Mendo, nao sayba ella disto nada... $\left(55^{\mathrm{v}}\right.$, col. a)

Henrique Lopes. "Cena Policiana." (De la misma colección citada en la entrada anterior). 
Fidalgo Polisiano: He de condiçao tao issenta

Felicena.

Pinarte: Que certeza quanto mor he atromenta dura menos sua braueza $\&$ he mais mansa quando assenta.

Teodosio: Este leo ja Celestina.

Pinarte: Polifema he cristalina \& por nossa parte à cosa.

[Polisano]: Temolhe que he muyto moça.

Pinarte: Mollier he, serà malina ... $\left(43^{\mathrm{r}}\right.$, col. a)

Teodosio: Onde vos manda nossamo.

Inofre: Cas Lycardo que estè prestes

Teodosio: pera a noyte.

tras amor com seu ??amo ?eixo.

Inofre: Muy bem dissestes porem amor desatina \& mais, Pinarte, empepina, a nossamo em se perder.

Teodosio: Esse velhaco ha de ser por tempo outra Celestina. $\left(45^{\mathrm{r}}\right.$, col. a)

Documento XXII: Libros recogidos en Puebla (México)(de los prohibidos):

"Celestina, que envió el Arcediano. Propaladia de Bartholomé de Torres Naharro (...)" (342);

"Tragicomedia de Calixto y Melibea, de Gregorio, esclavo de Francisco Velasco" (343);

"Celestina, sin principio ni fin, ni nombre de dueño" (343).

Citado de Francisco Fernández del Castillo, Libros y libreros en el siglo XVI, $2^{\mathrm{a}}$ ed., México: Fondo de Cultura Económica, 1982. 
Fray Juan de Pineda. Diálogos de la agricultura cristiana. Salamanca: Pedro de Adurça y Diego López, 1589. BNM R-17054.

"Por lo que dixistes del leer lo bueno y del no leer lo malo, pues basta saber ser tal, para lo huir: digo que muchas vezes he tenido rehiertas con otros mancebos que veo cargados de Celestinas, y leerlas hasta las saber de coro; y reprehendidos de mí por ello, se piensan descartar con dezir que allí se enseñan a huir de malas mugeres, y a conoscer sus embustes, y que viendo pintadas allí como al natural las carnalidades de los malos hombres y mugeres, darán más en rostro, y se apartarán dellas mejor (...) No ay cosa en el mundo tan atractiva, aun con solo pensarla, y aun sin ymaginarla; ¿y dezís que la leéis cómo se pone por obra para huirla? Ignorancia de gente sin sentido me parece, y muy peor la leción de Celestina que la de los libros de cauallerías en que no ay la práctica carnal, y ay otras virtudes muy platicadas, como lo de la honrra, verdad, amistad, criança y generosidad." (Libro II, Diálogo 22, sección 25, pág. 116a)

\section{6}

Lope de Vega Carpio. La bella malmaridada.

Mauricio (a Cipión), 11. 1846-1851:

Yo te daré una mujer

que, en corriendo la cortina,

es la misma Celestina

en el comprar y vender.

Con ésta escribe, y la envarga

este negocio.

Citado de la ed. de D. McGrady y Suzanne Freeman, Biblioteca Siglo de Oro, 6, Charlottesville, VA: Biblioteca Siglo de Oro, 1986, pág. 113. Hay otras muchas reminiscencias de lenguaje y situaciones encontradas en Rojas a lo largo de esta obra.

1600-1605

Romances del Romancero general (de los años 1600, 1604, 1605).

Núm. 117. "Otro romance" (págs. 84-85):

Incipit: Todos dizen que soy muerto, 
no debe de ser sin causa

(habla desde la tumba a varios, entre ellos, 11. 81-88)

Oídme, viejas Celestinas,

las que cubrís como mantas,

y en hombros, como cigüeñas,

sacáis avolar muchachas;

las ue de naturaleza

soléis enmendar las faltas,

adobando cerraduras

que ayer perdieron sus guardas.

Núm. 960 (Dozena Parte). "Letra" (págs. 106-107):

Incipit: La sangre sola te inclina

a que escuches muy de grado,

hijo amado,

a tu madre Celestina.

Ya sabes que siempre he sido

muy respetada en el mundo

y sin segundo, todo el tiempo que he vivido.

Explicit: Si te dixere de veras que riñas una pendencia, llana sentencia, que morirás en galeras.

Núm. 1334 "Otro romance" (págs 330-331):

Incipit: Despues que volví a mi casa la noche que con la vieja sobre imponer a mi dama tuve no sé qué revuelta;

Explicit: Llegado a encerraros ya, no tendreis las manos quedas, andad juntos al camino, que aquí la pluma se queda. Lo demás, os diré aparte, y esto baste, porque sepan las hijas de Celestina, como Ciliso se venga. 
Citado de la edición de Angel González Palencia, Clásicos Españoles IV, Madrid: CSIC, 1947.

\section{3}

Agustín de Rojas Villadrando. El viaje entretenido.

Despúes de que ROJAS haya dedicado unas buenas parrafadas en las que demuestra ciertos conocimientos de cómo las mujeres preparan afeites y pociones y de cuáles ingredientes:

Ramos: ¿De quién aprendiste todo este lenguaje del género femenino?

Rojas: Una vieja tuve por amiga, mayor hechicera y alcahueta que en su tiempo Celestina, ni que ha habido ni hay ahora en España. (...) Muchas cosas le vi hacer, y verdaderamente que para mí todas eran mentiras, embustes y quimeras, que ni hay hechizos, ni puedo entender que los haya. (103)

En lo que sigue, Rojas cuenta cosas de ungüentos, afición al vino, y otras cosas celestinescas relacionadas con esta amiga.

Más tarde, Rojas presenta una serie de ejemplos de las malas mujeres:

Rojas: La Madre Celestina dice que son las mujeres arma del diablo, destruición del paraíso, albañar sucio debajo de templo pintado. (222)

Citado de la edición de J. P. Ressot, Clásicos Castalia 44, Madrid: Castalia, 1995.

Gregorio González. El Guitón Honofre. Capítulo 6. "Refiere Onofre lo que le sucedió con el sacristán su amo y las pesadas burlas que lo hizo movido de hambre y necesidad."

"Hallé el panal en la boca del león y apliquélo a mi propósito como el letrado hace las leyes. Dios me vino a ver, que, aunque no me faltó cuidado, salí con mi empresa como Celestina con la suya." (115) 
Citado de la edición a cargo de Fernando Cabo Aseguinolaza, Logroño: Conserjería de Cultura, Deportes y Juventud, 1995.

Lope de Vega Carpio. La prueba de los amigos.

Clara: ¿Este tonto de tu amo

ha heredado?

Galindo:

Así es verdad;

el tonto y la cantidad he visto.

Clara: $\quad$ Aquí ay liga y ramo;

éste es páxaro que viene

dando en ella; no seas loco,

sino cayga poco a poco

con el dinera que tiene:

Galindo: A Celestina leí.

¿No has leydo a Çelestina?

Clara: Pues mira a Sepronio allí y por sus passos camina;

dexa, Galindo, a los dos

que este páxaro pelemos

$y$ tu parte te daremos.

Citado de la ed. de Henryk Ziomek, Athens, GA: U Georgia P, 1973, 11. 713-727.

\section{5}

Francisco López de Ubeda, Libro de entretenimiento de la Pícara Justina, Medina del Campo: Christobal Lasso Vaca, 1605. BNM R-9128.

Del Prólogo al lector en el cual declara el autor el intento de todos los tomos y libros de la pícara Justina:

"No es mi intención ni hallarás que he pretendido contar amores de tono del libro de Celestina (..) he huido de eso totalmente porque siempre que de eso trato voy a la ligera, no contando lo que pertenece a la materia de deshonestidad, sino lo que pertenece a los hurtos ardidosos de Justina." (17)

Del Prólogo sumario de ambos tomos de la Pícara Justina:

"Justina fue mujer de raro ingenio (...) [d]e conversacion suave, única en dar apodos, fue dada a leer libros de romance, con 
ocasión de unos que acaso hubo su padre de un huésped humanista que, pasando por su mesón, dejó en él libros, humanidad y pellejo. $Y$ así, que no hay enredo en Celestina, chistes en Momo, simplezas en Lázaro, elegancias en Guevara, chistes en Eufrosina, enredos en Patrañuelo, cuentos en Asno de Oro y, generalmente, no hay cosa buena en romancero, comedia, ni poeta español, cuya nata aquí no tenga y cuya quinta esencia no saque." (20-21)

Del melindre a la mancha:

[Se trata de una saya.] "¿Qué aliño para no mudar saya? ¡Vive Diez! No digo yo saya, pero a poder de miel cerotera, entraremos en tantas mudas, que mudemos el pellejo como la culebra o ciliebra, que así llaman unas benditas de mi barrio (...) [y] usan otros nombres a este tono, que los debieron de hallar en la calepina machona, a quien atribuyó la otra Melibea, que decía que este nombre asno se había de escribir con equis." (35)

Del melindre a la culebrilla:

Unos me diran: - Buena está la picarada, señor licenciado. Otro dirá: - Gentil picardía.

Otro: -iOh, qué pícaro libro!

Otro dirá: - Buena está la justinada.

Otros: - Bueno es el conceptillo, agudo pensamiento, gánasela a Celestina y al Pícaro. $39-40$

Del Libro Primero. cap. iii. 'De la vida del mesón.' No. Segundo. 'De la mesonera astuta.'

"Yo, hermano lector, ya adivino que en oyendo quien fue mi madre, te has de santiguar de mí como de la Bermuda. ¿Qué quieres? Diérasme tú otro molde y saliera yo más amoldada. Soy fruta de aquel árbol y terrón de aquella vena. ¿Qué me pides? Escucha y oirás las hazañas de otra Celestina a lo mecánico." (77)

Sextillas unísonas de nombres y verbos cortados:

Yo soy due-

Que todas las aguas be-

soy la reina de Picardi-

mas que la ruda conoci- 


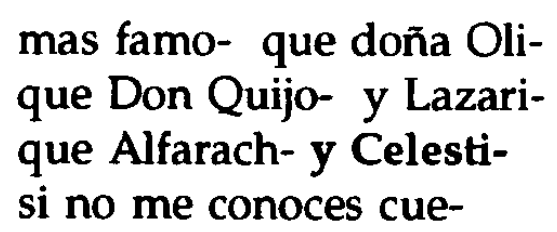

Yo no (error por soy?) due-

Que todas las aguas be- (258)

1606

I.A. Leonard (Books of the Brave, p. 297) informa que los documentos muestran que ejemplares de Celestina fueron mandados a Cuzco (Peru) con Juan de Sarria.

En los protocolos de Francisco Dávalos (Archivo Nacional del Perú, fols. $\left.342^{v}-344\right)$, se anota la existencia de "3 Celestinas .... pessos 2" (I. A. Leonard, Books of the Brave, p. 401).

\section{7}

Fernando de Rojas. Tragicomedia de Calixto y Melibea: en la qual se contienen (demas de su agradable y dulce estilo) muchas sentencias philosophales y auisos muy necessarios para mancebos, mostrandose los engafios que estan encerrados en simientes y alcaheutas [sic]. Agora nueuamente corregida y emendada. Zaragoza: Carlos de Labauyen y Juan de Larumbe, 1607.

1609

Juan Angel de Andrada. Corrección al acto VII al Santo Oficio (Arch. Hist. Nac. Inquisión leg. 4468, \#2. Exp. 948).

8 agosto 1609. " ... contra todas las personas que ubieren leydo algunas proposiciones o cosas mal sonantes en algún libro, dixo que denunciaba y denuncio que un libro llamado Celestina, en el acto séptimo a nuebe fojas del, dice unas palabras dignas de corregir y enmendar y quitar, que dicen asi hablando con una muger: por hermosa te tenía hasta agora, viendo lo que todos podían ver, pero agora (...) no te las dio Dios para que pasasen en balde por el frescor de tu jubentud, debajo de seis dobleçes de paflos y lienço: que la impresión del dicho libro es en Seuilla en la imprenta de Alonso de Barrera año de 1599 (...)." . 
Francisco Martínez, denunciando el pasaje del acto I del primer encuentro entre Calisto y Melibea, extrañándole que no lo hubiera corregido la Inquisición. (Arch. Hist. Nac. Inquisición leg. 4469, \#31.)

19 octubre 1609. "En el librillo de Celestina, en el principio de el yntroduçe el autor un mançebo libiano diçiendo entre otras cosas: que los ángeles en el çielo no tienen tanta gloria en prencia de Dios como el en presencia de su amiga; este libro le vi en Malaga abra un año y leyendo las primeras ojas de el di con estas palabras, $o$ otras equivalentes $y$ ofendido de semejenate comparacion, mire el titulo del dicho libro y deçia estar corregido por el Santo Officio, a muchos a parezido mal la dicha exageraçion sin embargo que el dicho mançebo se yntroduçe alli como apasionado, y como hombre que esta fuera de si $y$ an denunciado de las dichas palabras. No enbio a vuestra señoria el dicho libro, por que no se halla en toda esta ciudad, ni se en que capitulo estan mas de que es al primero del libro."

Francisco de Quevedo. España defendida y los tiempos de ahora, de las calumnias de los noveleros y sediciosos (MSS autógrafo fechado el 20 de septiembre de 1609). Del cap. IV: "De la lengua propia despaña."

"Pues dime, dejando las cosas grandes; ¿quién tienes en ninguna lengua, entre griega, hebrea, latina y las buestras, todas ocupadas en seruir a la blasfemia, qué tenéis que comparar con la trajedia exemplar de Çelestina? con Lazarillo? ¿dónde ai aquella propiedad, grazia i dulzura?"

Citado de la edición de $\mathrm{R}$. Selden Rose, separata del Boletín de la Real Academia de la Historia 68-69 (1916), con páginación propia, en la pág. 69. BNM VCa 170/28.

\section{0}

César Oudin. "Diálogo octavo, entre dos amigos, el vno llamado Polígloto, y el otro Philoxeno, en el qual se trata de algunas cosas tocantes al caminar por España, (...)."

Polígloto: ... y a la mañana siguiente tomè el camino de Salamanca (...) yo ví allà los Colegios (...) y el Toro, que està a la entrada della, del qual habla Lazarillo de Tormes.

Philoxeno: Vió allí vuestra merced la casa de Celestina? 
Polígloto: Señor, me dixeron el lugar donde estaua, mas no tuue tanta curiosidad que fuera a ella, y también porque me parece que es cosa fingida.

Citado por Marcel Gauthier, en "Diálogos de antaño, reéditos," Revue Hispanique XLV, núm. 107 (febrero 1919), pp. 151-152.

Alonso Jerónimo de Salas Barbadillo. La hija de Celestina.

"De modo fue, amigo, lo que te cuento que sucedió en realidad de verdad que hubo año y aun años que pasaron más caros los virgos contrahechos de su mano que las naturales. ¡Tan bien se hallaban con ellos los mercaderes deste gusto! (...) Como el pueblo llegó a conocer sus méritos quiso honralla con título digno de sus hazañas y así la llamaron todos en voz común "Celestina", segunda desta nombre. Pensarás que se corrió del título. ¡Bueno es eso! Antes se estimó tanto que era el blasón de que más cuenta hacía." (45)

'El abundancia alivia la tristeza; sabed que es poderosa medicina para todos los males la riqueza.' ¿Que bien que alega esto Celestina! Si ella lo dijo bien, mejor lo siento. Yo soy la que comenta su doctrina.' (52)

[Síguese la doctrina referida]

'...Lo demás es dudoso; aquesto es cierto.

Esto habéis de seguir que es la luz clara que os llevará seguras hasta el puerto.' Así predicando vieja avara; secta de Celestina introducía, mostrando sus deseos en la cara.' (57)

Citado de la edición de José Fradejas Lebrero, Clásicos Madrileños 2, Madrid: Inst. de Estudios Madrileños, 1983. 
Pierre de Bourdeille. Rhodomontades et gentilles rencontres espagnoles. Citado de la traducción inglesa, Spanish Rhodomontades, de Mr. Ozell, London: J. Chrichley, 1741, pág. 148 y nota.

"A Lady asked a Gentleman for a book called Celestina"; he answered her; Por Dios, Señora, que me espanto de Vuestra Merced, Teniendo en Casa el Original, pedir el Traslado."

* (nota) "A Famous Spanish Tragi-Comedie, called Celestina, which represents a wicked old Bawd, so called. It was the usual proper name of a Woman, but little used since that Play was writ."

\section{4} Celestina).

Alonso Jerónimo de Salas Barbadillo. La ingeniosa Elena (la hija de

Soneto del Licenciado Juan Francisco Bonifaz y Tovar, elogio a Salas Barbadillo en los materiales preliminares a su La ingeniosa Elena, los tercetos finales (no aparece en la ed. de 1612):

Mas tanto vuestro ingenio se engrandece

en creación tan alta y peregrina

que habéis lo natural aventajada.

A Elena vida dais, por vos merece

que conozca a su madre Celestina

y a vos os deve el ser que le avéis dado.

Francisco Ortiz. "Apología en defensa de las comedias que se representan en España," en Libro de treçe curiosos y dibersos tratados recopilados en el anno 1614, fol. 186v. BNM MS 287.

¿Quién duda sino que ese librillo de Celestina es de los más discretos y sentenciosos que hay escritos? Pero es una flor de la cual saca miel, que si lo lee un hombre docto, nota las sentencias de todos los filósofos, dichas por la boca de aquella vieja y sus consortes, y queda avisado para saberse guardar de alcahuetas y rufianes. Pero si o lee un ignorante, no entiende lo bueno, y solamente le queda en la memoria la raza que tuvo Calixto para entrar a hablar a Melibea, siendo el intento del libro bien diferente."

Citado de la edición de Louis Pérez, Estudios de Hispanófila 45, Chapel Hill, North Carolina: Hispanófila, 1977, p. 86. 
Alonso Fernández de Avellaneda. El ingeniosos hidalgo Don Quijote de la Mancha (que contiene la tercera salida y es la quinta parte de sus aventuras). Tarragona: Felipe Roberto, 1614. BNM R-32541.

No me murmure nadie de que se permitan impresiones de semejantes libros, pues éste no enseña a ser deshonesto, sino a no ser loco; y permitiéndose tantas Celestinas que ya andan madre e hija por las plazas, bien se puede permitir por los campos un don Quijote y un Sancho Panza a quienes jamás se les conoció vicio; antes bien, buenos deseos de desagraviar huérfanos y deshacer tuertos, etc. (Parte 6, cap. 24, p. 184)

Fernando de Rojas. Celestina. Tragicomedie van Calisto ende Melibea ... Amberes: Heyndric Heyndricz, 1616 (BL 11725.a.7).

Alonso Jerónimo de Salas Barbadillo, El sagaz Estacio, marido examinado. En la dedicatoria 'A Don Agustín Fiesco, Caballero Nobilísimo de la República de Génova,' defiende su obra (en prosa) por haber tantas obras semejantes publicadas y apreciadas en Italia y dice:

"... supuesto que en Castilla no tenemos más que una [comedia en prosa], que es La Celestina, bien que ésta, aunque única, es de tanto valor que entre todos los hombres doctos y graves, aunque sean los de la más recatada virtud, se ha hecho lugar, adquiriendo cada día venerable estimación, porque entre aquellas burlas, al parecer livianas, enseña una doctrina moral y católica, amenazando con el mal fin de los interlocutores a los que les imitaren a los vicios."

Citado de la edición de Madrid: S.A. de Promociones y Ediciones, 1980, p. 111.

Lope de Vega, Fortunas de Diana en el libro La Fiomena, Madrid: viuda de Alonso Martín, 1621. 
"Celio, cuando pudo, se llego a ella qe fue lo más que pudo con su turbado atrevimiento, y al pasar Diana, le dijo: ' $i$ Que deseada tenía yo esta visita!' A quien ella respondio con agradable rostro: '¿No estáis engañado?"'

"Aquí me acuerdo, señora Leonarda, de aquellas primeras palabras de la tragedia famosa de Celestina, cuando Calisto de dijo: 'En esto veo, Melibea, la grandeza de Dios.' Y ella responde: '¿En qué, Calisto?' Porque decía un gran cortesano que si Melibea no respondiera: '¿En qué, Calisto?', que ni había libro de Celestina ni los amores de los dos pasaran adelante. Así ahora, en estas dos palabras de Celio y nuestra turbada Diana (...)."

Citado de Lope de Vega, Obras escogidas, tomo II Poesías líricas. Poemas. Prosa. Novelas, ed. F. C. Sainz de Robles, Madrid: Aguilar, 1964, p. 1324ab.

John Minsheu, A Dictionary in Spanish and English, first published into the English tongue (...), London: John Haviland for William Aspley, 1623, pp 78-79 de los materiales posliminares.

Minsheu llega a la p. 51 de la sección, Words, Phrases, Sentences and proverbs, out of 'Celestina' in 8. Printed at Antwerp En la oficina Plantiniana, Anno 1595, y luego escribe: "After I had read ouer Diana de Monte mayor, and other authors (...) and being come thus farre in Celestina, as you see, it came into my imagination (...) not to deale all at once, but to keepe some to sweeten their mouths [ = men of mine own profession] (...)." Luego continuá así con Lazarillo, Menospecio de corte, etc.

1624

Tomás Tamayo de Vargas. "Junta de libros, la maior que españa ha visto en su lengua hasta el año de 1624." BNM MS 9753, fol. 89 recto $y$ verso.

"Rodrigo Cota, llamado el Tío, de Toledo, escribio estando en Torrijos debajo de vnas higueras, de las casas de Tapia, el Acto primero de Scelestina, Tragicomedia de Calisto i Melibea, libro que a merecido el applauso de todas las lenguas. Alguno a querido que sea parto del ingenio de Iuan de Mena, pero con engaño, que facilmente prueba la lengua en que está escripto mejor que la del tiempo de Juan de Mena. Salamanca por 
Matthias Gast. 1570. 12. Esta es la mejor de todas las impressiones que se an hecho deste festiuissimo librillo."

Caspar von Barth. Vltima verba Melibaeae ad parentem pleberivm privs quam, post casv mortuum Amasium suum Callistonem, se turri praecipitaret. Ex Hispanico Ludo. Celestina. En Musaei Vetustissimi, venustissimique Poetas Graeci Erotopaegnion Heros et Leandri (...) commentarii a libro illustrauit Daniel Parevs. Frankfurt: G. Fitzeri, 1627. BL 76.d.26.

\section{1}

Francisco de Quevedo, "A los que leyeren esta comedia," prefacio a la edición de Eufrósina, traducción al castellano por Fernando Ballesteros y Saavedra de la obra de Jorge Ferreira de Vasconcelos, Madrid: Impta. del Reino, 1631.

"Pocas comedias hay en prosa de nuestra lengua, si bien lo fueron todas las de Lope de Rueda; mas para leídas tenemos la Selvaga, y con superior estimación la Celestina, que tanto aplauso ha tenido en todas las naciones."

Fernando de Rojas. Tragicomedia de Calisto y Melibea por el Bachiller ... Aora nvevamente corregida y emendada y impressa conforme al Expurgatorio nuevo de 1632. Madrid: viuda de Alonso Martín, 1631 (fecha en el colofón). 196 folios. Sin ilustraciones, sin argumentos de los actos y sin los versos posliminares. BNM R-12948.

James Mabbe, translator. Fernando de Rojas. The Spanish Bawd ... London: J. B. for Robert Allot, 1631.

1632

Lope de Vega Carpio. La Dorotea. Madrid: Imprenta de la Reina, 1632.

Del prefacio "Al teatro" por Francisco López de Aguilar (pseud. del mismo Lope):

"Aquello se usaba entonces y esto agora, que así lo dijo Horacico (...) más antiguas son las comedias de Aristófanes, Terencio y Plauto, y se leen con lo que usaban entonces Grecia y Roma; y 
entre las nuestras, más cerca de nuestros tiempos, la Celestina castellana y la Eufrósina portuguesa." (62)

Citado de la edición de E. Morby, Madrid, Castalia, 1980.

\section{4}

The Rogue, or the Life of Guzmán de Alfarache (...) to which is added the Tragi-Comedy of Calisto and Melibea; represented in Celestina. $3^{\text {rd }}$ ed. corrected. London: Robert Allott, 1634. BL 645.1.12. La TCM ofrecida es la de 1631, publicado por el mismo Allott.

1647

Gaspar de Avila y Perea. La gram comedia del Familiar sin Demonio nueua jamás vista nin representada. S. I.: Vicente de Lemos, 1647. BNM T7594.

Act II, fol. $12^{r}$, col. a:

Martín: Iesus mil vezes!

D. Juan: Que has visto?

Martín: No basta auer escuchado?

era contigo donado

el ingenio de Calisto,

en quanto toca a un enredo.

Como has de poder salir

desta trampa? piensas ir?

Act II, fol. $15^{\mathrm{r}}$, col. b - 15 ${ }^{\mathrm{v}}$, col. a:

D. Juan: Pues ahora, di, que infieres

de la confusión primera

en que estabas?

Martín: Que quisiera

publicar a voces, que eres

en lo sutil de tus lazos

por sietecientas razones

Celestina con calzones

y vn Merlín sin embarazos. 
Baltasar Gracián. Agudeza y Arte de ingenio, discurso 56, "De la agudeza compuesta fingida en especial."

Sobre los recursos alegóricos:

"Algunos de los españoles los han favorecido, como el trágico maestre do Alvaro de Luna en sus carrozas de las Heroides, y el encubierto aragonés en sus ingeniosísima Tragicomedia de Calixto y Melibea. No los franceses los despreciaron."

(Menéndez Pelayo opina que Gracián, aragonés, asociara la TCM con Pedro Manuel de Urrea, otro aragonés, y su égloga de Calisto y Melibea, de 1513.)

Citado del $2^{\circ}$ tomo de la edición de Evaristo Correa Calderón, Clásicos Castalia 15, Madrid: Castalia, 1969, pág. 202.

Jerónimo Cáncer y Velasco, "Entremés famoso de los putos" (impreso en Ociosidad entretenida en varios..., Madrid: Anglés de la Iglesia, 1668).

Doctora: Por las muelas de un ahorcado me traen aquí mis desvelos.

Toribio: ¿Qué fantasma es ésta, cielos? Válgame un Credo cantado.

Doctora: A esto mi intento camina.

Con traje y presencia tal, como manda el ritual de la Madre Celestina.

Edición moderna en Javier Huerta Calvo, Textos breves de los siglos XVI y XVII, Temas de España 148, Madrid: Taurus, 1985, pp. 230-234.

Baltasar Gracián. El criticón. Parte Segunda. Huesca: Juan Nogués, 1653. Del Crisi IV, "Museo del Discreto":

"De la Celestina y otros tales, aunque ingeniosos, comparó sus hojas a las del peregil, para poder passar sin asco la carnal grosería." 
Citado de la edición de Santos Alonso, Letras Hispánicas 127, Madrid: Cátedra, 1984, pág. 375.

Francisco de Portugal, Arte de galantería. Lisboa, 1670, pág. 49.

Afirma el autor que Diego de Mendoza, cuando se fue en una embajada a Roma, se llevó sólo un ejemplar de Amadís y otro de Celestina, a la vez insinuando que éstos le gustaron más que las epístolas de San Pablo.

\section{4}

Luis de Ulloa Pereira. "Defensa de Libros fabulosos y poesías honestas y de las comedias que ha introducido el vso, en la forma que oy se representan en España," en Obra de don .... Madrid: Francisco Sanz, 1674, págs. 352-354. BNM R-22519.

"En las Comedias Castellanas no las ay [torpeças], antes su estilo se va desvaneciendo de manera que mas por remontado que por baxo se aparta de la propiedad. Tan lexos està de ser deshonesto ni grossero: $Y$ si algunos hyperboles se ponen en boca de los amantes, nunca es con animo de aplaudirlos, ni aprobarlos, de manera que por esto pueden parecer idolatras, aun quando mas se desordenan. Frenetico Calisto, con la passion amorosa, y reprehendido de Sempronio, dize: 'Que se me da a mi?' $Y$ replicándole: 'pues tu no eres Christiano?' responde: 'Yo Melibea [sic] soy'; y prosigue con desatinados encarecimientos que justa y santamente se mandaron borrar en el vltimo expurgatorio, no queriendo fiar mas tiempo a la expeculacion de los vulgares, lo que muchos años se auía dissimulado, en consideracion de la moralidad que se emboluia en aquellos delirios, aduirtiendose en ellos la fuerça del afecto amoroso, que turbando el juizio, ocasiona semejantes locuras, por que todos estèn preuenidos, sin dexar portillo por donde pueda introducirse enemigo tan poderoso, y permitiòse lo demás del libro, en que no faltan tropieços, por ser su intento mostrar los malos fines que tienen quantos tratan amores deshonestos, y sus solicitadores y terceros: que escarmentan en males agenos es prudencia, tenerlos a la vista, mediana: vsar mal dellos, ignorancia ò malicia." 
Agustín de Salazar y Torres, El encanto es la hermosura y el hechizo sin hechizo. En Cítara de Apolo, Madrid: Francisco Sanz, 1681.

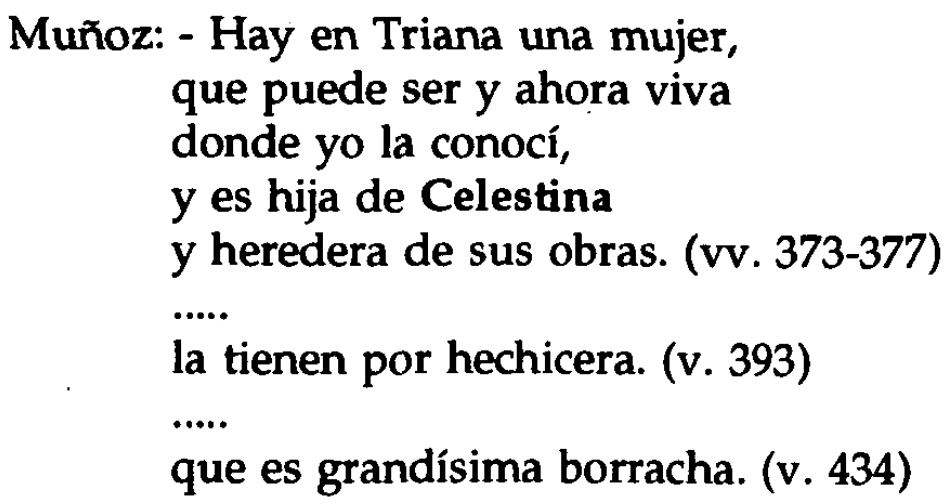

Celestina: - La que vive de su oficio trabaje: ... (vv. 475-476)

(a Doña Ana) - Cuando vuelvas yo estaré en tu casa, con pretexto de vender las bujerías que son al uso estos días. (vv. 682-684)

\section{9}

"1677-78 y 1679 - Se representan en el Coliseo las Comedias de Agustín Salazar y Torres (...) tituladas 'Elegir al enemigo,' 'Los juegos olímpicos,' 'El encanto es la hermosura' y 'Hechizo sin hechizo,' una especie de segunda parte de La Celestina de Fernando de Rojas."

Citado de Armando de María y Campos, Guía de representaciones teatrales en la Nueva Espafia (siglos XVI y XVII), México, D.F.: B. Costa-Amic, 1958, p. 98.

\section{4}

Gaspar Agustín de Lara. Obelisco Fúnebre (...) a la inmortal memoria de don Pedro Calderón de la Barca. Madrid: por Eugenio Rodríguez, 1684. BNM R-27893.

De "La memoria de comedias de D. Pedro Calderón, embiada al (...) Duque de Veragua":

El Castillo de Lindabrides

Don Quijote de la Mancha 


\section{La Celestina}

No hay cosa como callar...

Se vio Martes de Carnestolendas del año 1696 (6 de marzo), bajo la supervisión de Carlos Vallejo, en el Buen Retiro, Salón de los Reinos, una versión de la Celestina de Salazar y Torres.

Citado en John Varey and N. D. Shergold, with Charles Davis, Comedias en Madrid, 1603-1709; repertorio y estudio bibliográfico. Colección Tamesis, Serie C, Fuentes para la historia del teatro en Espafta 9, London/Madrid: Tamesis Books y la Comunidad de Madrid, 1989, pág. 216.

\section{7}

John Stevens, translator. The Spanish Libertines: or, the Lives of Justina, the Country Jilt; Celestina, the Bawd of Madrid; and Estevanillo Gonzales, The most Arch and Comical of Scoundrels. To which is added a Play call'd An Evening's Adventures. All Four written by Eminent Spanish Authors, and now first English'd by Captain John Stevens. London: Samuel Bunchley, 1707. BL 12491.f.30. (The preliminary pieces, the 'argumentos' and end pieces are not translated here, and there are no illustrations. The arrangement of the text is now in nine 'chapters'.)

"The Originals have a good Reputation among all that are Masters enough of the Spanish tongue to understand them, and have been well receiv'd in their own Country (...) The design of them is not to Teach those vile Practices they contain, but rather to expose Vice, and the base Contrivances of Scandalous Persons." (fol. A2)

"The second piece (...) Celestina Tragicomedy of Calisto and Melibea being in the nature of a Play, and therefore call'd a Tragedy, but has too many Acts, so that it would never appear in its Natural Dress, which prevail'd with me to alter the Method, retaining still the whole Intrigue, without Deviation from it in the least, but only making a Tale of it, and therefore the Dialogue is kept up in a great measure; the Book is well known and esteem'd in the Original (...) The whole is a continual Contrivance of Lewdness, dexterously manag'd, with such an intermixture of superstitious Follies as renders it pleasing, discovers the Ignorance of those who believe in such Absurdities, 
and gives a good caution for the shunning all Women of Scandalous Reputation, by the Example of Melibea." (fols. $\mathrm{A3}^{\mathrm{rvv}}$ )

1734

Francisco Botello de Moraes i Vasconcelos, Historia de las cuevas de Salamanca. Leon de Francia: s. i., 1734². BNM R-2881.

Entre los poemas preliminares, hay uno anónimo, "Privilegios que la madre Celestina concedió al Caballero Francisco Botelho de Moraes" (págs. 11-18):

Incipit: Yo Celestina la Astuta,

Por merced de Satanás

Emperatriz poderosa

D'el embuste, i la maldad

Princesa de quantos montes

Vomitan fuego infernal (...)

(...) Reina sagaz

D'el Titiritero, de

La Alcahueta, i d'el Rufián. (...)

Explicit: Fecha en mis inclytas grutas,

En el año mas manual.

La Emperatriz Celestina.

De orden de su magestad

Firmò abaxo el Secretario

Cachidiablo de Satán.

" ... propuse escribir una exacta i verdadera Historia de dichas Cuevas (...) Examiné una en las peñas que no lexos d'el Colegio d'el Rei dominan el Tormes, i se llama la Cueva de la madre Celestina i de la qual averigue no pocos portentos." (pág. 43)

En la Cueva se encuentra con una mujer de horrible apariencia, que le dice:

"I te digo (volviendo a mirarme) que foi la Madre Celestina, $i$ vivo Excelsa $i$ coronada en mi Cueva junto al Colegio d'el rei (...)." (págs. 64-65) 
Gregorio Mayans y Siscar. Vida de Miguel de Cervantes Saavedra (al frente de una edición de Don Quijote, a modo de Prólogo).

I las mejores Comedias que tenemos en Español, que son LA CELESTINA, i EUFROSINA, están escritas en prosa. De la CELESTINA dijo el docto Autor del Diálogo de las lenguas [sic], que quitando algunos vocablos fuera de propósito, $\mathrm{i}$ algunos otros Latinos, era de opinión, que ningún libro escrito en Castellano, adonde la lengua estè mas natural, mas propia, ni mas elegante. I despues de èl, dijo Cervantes, que era libro en su opinion Divino, si encubriera mas lo Humano: juicios, que segun el mio, totalmente quadran también a LA EUFROSINA. (185)

Las COMEDIAS ... CALISTO, I MELIBEA, ... CELESTINA, Alcahueta tan infame, como famosa por el incierto Autor, que primero la ideò, empezò a dibujar, i colorir; por el Bachiller Fernando de Rojas, que le diò fin, no pudo igualar al primer inventor. (215)

Citado de la ed. facsímil de la ed. de Madrid: a costa de Don Pedro Joseph Alonso i Padilla, 1750.

1738

Louis Adrien Du Perron de Castera, comp. Extraits de plusiers pièces du théatre espagnole. París: Viuda de Pissot, 1738.

"Pour des Tragédies, les Espagnols n'en font point; car on ne sçauroit donner justement ce titre à quelque-uns de leurs Ouvrages, qui le portent sans le mériter: telles sont la Célestine et l'Ingenieuse Helene, qui ne peuvent passer tout au plus que pour des Romans en dialogues." (pág. 4 del prefacio)

\section{7}

Se manda expurgar en castellano, y corregir en otras lenguas, varias ediciones de Celestina: mencionando específicamente las de Sevilla 1539 y 1599; las de Salamanca 1558 y 1570; las de Alcalá de 1536, 1569 y 1591; y la de Madrid 1601.

Datos en Miguel de la Pinta Llorente, La Inquisición Espantola y los problemas de la cultura y de la intolerancia, Madrid: Ed. Cultura Hispánica, 1953, I: 102ss. 
Antonio Blas Nasarre y Ferriz. Comedias y entremeses de Miguel de Cervantes Saavedra. Madrid: Impta. Antonio Marín, 1749, BNM R-32711.

"Los hombres de juicio [que leían y observaban la naturaleza, y los primores de los autores Griegos y Romanos] conocieron quán apartados estaban del buen gusto y de la cordura; y detestaron del abuso que se hacia del Dialogo para corromper el corazon y el juicio. Por esso escribieron Dialogos que llamaron Comedias; pero muy largos è incapaces de representarse. Los Portugueses se aplicaron mucho à esta composicion, pero no nos faltan Comedias de este jaez (...) Las Comedias Florinea; La Selvagia; La Celestina; La Eufrosina, son admirables en esta classe y pudieran tener buen uso si se emendassen algunos passages de ellas demasiadamente lascivos, y malignos, en los quales se muestra la deshonestidad del todo desnuda, con el pretexto de azotarla." (fols. $\mathrm{B}^{\mathrm{v}}-\mathrm{B}^{\mathrm{r}}$ )

Luis Josef Velázquez. Orígenes de la poesía castellana. Citas de la $2^{a}$ ed. Málaga: Herederos de Francisco Martínez de Aguilar, 1797. BNM U-3397.

"Pero es menester confesar que [estos] ... no fueron los que en sus composiciones mas se esmeraron en desterrar del drama todo lo que podia ser perjudicial a las buenas costumbres, habiendo en muchas de sus comedias escenas demasiadamente lascivas, y pasajes llenos de no poca malignidad. Tal es la famosa Celestina 6 tragico-comedia de Calixto y Melibea, en que hay descripciones tan vivas, imágenes y pinturas tan al natural, y caracteres tan propios, que por eso mismo serían de malísimo exemplo, si se sacassen al teatro. Ignórase el principal autor de esta comedia, atribuyéndola unos á Juan de Mena, y otros á Rodrigo de Cota; pero se sabe que el que la comenzó no pasó del primero acto, habiéndola continuado después desde el segundo, no con igual acierto, el Bachiller Fernando de Rojas, como parece por unos versos acrósticos del mismo (...) Esta comedia, como todas las más de aquel tiempo, se escribió en prosa; y después la puso en verso Juan de Sedeño, que la publicó en Salamanca en 1540. Los Franceses tienen de ella dos traducciones; la más antigua,hecha por autor incierto y publicada en leon de Francia 
1529, y en París 1542; y la segunda por jacobo Lavardin en París 1598." (págs. 83-84)

Gregorio Mayans y Siscar. Rhetorica. Valencia: Herederos de Gerónimo Conejos, 1757. Libro II, capítulo xii 'De la narración fingida,' n. 37:

La Scelestina, de incierto autor; el Celoso, de Alonso de Uz; i la Eufrosina, de Jorge Ferreira de Vasconcelos, son comedias escritas en prosa, $i$ otras muchas; verdad es que essas más pueden tenerse por novelas que por comedias, para ser leídas y no representadas.

Citado de las Obras completas de Mayans y Siscar, ed. Antonio Mestre Sanchis, Oliva: Ayuntamiento, 1984, III: 279.

Luis Josef Velázquez. Orígenes de la poesía castellana (ver arriba 1754). En traducción alemana por J. A. Dieze, Gotinga, 1769, se anaden estas ideas: "[Celestina] consta de 21 actos que más bien podrían llamarse secciones; no parece estar hecha para la representación, y por eso es más apropiado tenerla por una novela dialogada." (307)

\section{h. 1772}

Nicolás Fernández de Moratín. Arte de las putas (prohibido el 2 de junio de 1777).

Yo, en fin, como mujer que bien lo entiende

(me está mal el decirlo, pero es cierto)

en buen hora lo diga, ha cuarenta años

sirvo a grandes de España y religiosos,

a señoras y a monjas, y ninguna

por mí ha perdido, aunque sufrí seis veces

mitras, encierros, troncho, burro y plumas.

Pero a mi oficio venga quien quisiere:

venga la Tía Taya, la Rosana,

la Madre Anica, o doña Mari-Pérez,

o venga la beata santurrona

alcahueta de clérigos y frailes.

Pasan de seis mil virgos en la Villa 
por mi autoridad deshechos y hechos.

Niña de teta fue la Celestina

pues sé yo más embrollos e ingredientes

para cien ministerios diferentes;

pero porque envilece la alabanza

en boca propia, callo ... (pág. 118, ll. 460-478)

Citado de la edición de Enrique Velázquez, Colección Memorias Corporales, 1, Madrid: A-Z Ediciones, 1990.

José Cadalso, "El buen militar a la violeta. Lección póstuma del autor del tratado de «los Eruditos»." Madrid: Sancha, 1772.

"Los libros que debe leer con más frecuencia son el Cándido o el optimismo, de Voltaire; Les Matinées, de Citerée, y las Macarrónicas, de Stopini, leyendo y releyendo con cuidado la que lleva el título De malitiis Puttanarum, Macarronea Prima, porque pueden serle útiles sus instrucciones; sin olvidar la famosa tragicomedia de Calixto y Melibea, porque, al mismo tiempo que autoriza su conocimiento en nuestros autores antiguos, contribuirá a preservarle de los engaños y ardides de las madres viejas zurcidoras, de quienes le será preciso servirse en sus incursiones al país de las delicias (...)."

Citado de Los eruditos a la violeta, ed. prólogo y notas de José Luis Aguirre, Biblioteca de Iniciación Hispánica, Madrid: Aguilar, 1967, p. 215.

Jerónimo de Zurita. "Dictamen de .... acerca de la prohibición de obras literarias por el Santo Oficio." BNM, MS autógrafo.

"Ay tambien algunos tratados que aunque escritos con honestidad el subjecto son cosas de amores, como Celestina, Carcel de amor, Question de amor y algunos desta forma, hechos por hombres sabios; algunos, quiriendo imitar éstos han escrito semejantes obras con menos recato y honestidad, como la Comedia Florinea, La Thebayda, La resurection sic de Celestina y Tercera y Quarta que la continuaron; éstos segundos todos se deben vedar, porque dicen las cosas sin arte y con tantos gazefatones que ningunas orejas honestas los deben sufrir (...) 
que auiendo en la lengua española tan buenos ingenios está muy falta de libros bien escritos y que la ubieran illustrado, como se ha hecho en la italiana y en la francesa, y si algunos pocos ay en semejantes materias pudiendose sufrir no se debrian quitar; tales son la primera Celestina, las obras de Boscan, las de Garcilaso, las de Diego de Mendoza."

Citado de M. Serrano y Sanz, Revista de Archivos, Bibliotecas y Museos, Tercera Época, Año VII, tomo 8.1-3 (1903), pág. 220.

\section{h. 1780}

Juan Pablo Forner. Exequias de la lengua castellana.

Está elogiando los 'hombres respetables' de las letras españolas y ha llegado a los dramaturgos:

"Bartolomé de Torres Naharro, Lope de Rueda y otros más antiguos seguían a esta tropa, y en pos de ellos los trágicos Fernán Pérez de Oliva, Jerónimo Bermúdez, Cristóbal de Virués, Juan de la Cueva y Tanco de Fregenal, que venían a rematar en el autor y en el continuador de Celestina" (167-168).

Citado de la edición de Pedro Sainz Rodríguez, Clásicos Castellanos 66, Madrid: Espasa-Calpe, 1925 reimpreso en 1967.

\section{7}

Padre Juan Andrés, S. J. (La traducción española del original italiano de 1784.) Origen, progresos y estado actual de toda la literatura, vol IV (Madrid: Antonio de Sancha, 1787), págs. 123-131. Traducido por D. Carlos Andrés.

"Los Españoles pretenden que la gloria de ser la primera composición dramática escrita con elegancia y regularidad se daba á su Celestina, antes que al Orfeo de los Italianos" (123124).

Sigue a decir que rechaza a Cota como autor y que no le parece muy cierto Juan de Mena.

"Los Españoles ... quando con noble ardor promovieron toda especie de poesía, y se adquirieron no poco crédito en la dramática, ilustraron de varios modos la Celestina" (128). 
Dice que posee la ed. de Barcelona 1560 y que Mayans y Siscar tiene la de Valencia 1575.

\section{h. 1788}

De una carta escrita por el poeta salmantino, José Iglesias de la Casa, a Juan Pablo Forner, nos enteramos de que "prestó un tal Villafañe un libro á [Ramón] Caseda, éste a Melendez, y Melendez hízose prenda de él, porque Caseda le destruyó una Celestina, que tampoco era de Melendez, sino del maestro Alba."

Citado del tomo I de Poetas líricos del siglo XVIII, colección formada por Leopoldo Augusto de Cueto, en Biblioteca de Autores Españoles 61 (Madrid: Atlas, 1952), pág. cxvi.

\section{0}

Gaspar Melchor de Jovellanos. "Memoria sobre los espectáculos públicos" (Gijón, 29 septiembre de 1790).

"Bástenos decir que a los fines de aquel siglo [XV] tenemos ya en la Celestina un drama, aunque incompleto, que presenta no pocas bellezas de invención y de estilo, dignas de aprecio, si no de la imitación, de nuestra edad. $Y$ tal es el origen de nuestra escena profana." (28-29)

"Sin duda la Celestina, las comedias de Naharro y las tragedias de Fernán Pérez de Oliva prueban que el buen gusto dramático rayó muy temprano entre nosotros. Es bien sabido que la primera fue escrita en el siglo $X V$, aunque continuada y acabada mucho después (...) Mas aunque las comedias de Naharro fueron representadas con mucho aplauso en Nápoles (...) no sabemos que ni ellas, ni la Celestina, ni las tragedias de Oliva, hubiesen subido jamás a nuestras tablas; y la imperfección en que permaneció nuestra escena por mucho tiempo hace creer que no era capaz todavía de tanta cultura y artificio." (30)

Citado de la edición de Biblioteca Básica Autores Asturianos 1, Gijón: La Voz de Asturias, 1991. BNM VCa 20594/13.

1791

Sacada de la causa de Dn. Luis Paret sobre la Comedia de Celestina. 19 noviembre 1791 (Arch. Hist. Nac. Inquisición, leg. 4483, \#13) 
(1) "... en una declaración hecha en Bilbao à tres de marzo por Dn. Christoval del Cotarro, presbitero el la qual denuncia à dicho Paret, por tener varios libros prohiuidos (...) [t]ambien hace memoria de haberle hablado (Paret) de cierta obra, que cree era una Tragicomedia llamada la Celestina, que presume tenia en su poder (...)."

(2) "Que examinado como contexte acerca de lo principal, el medico Luxurriaga en Bilbao a cinco de Abril deste año dice (...) [q]ue el expresado Dn. Luis Paret tubo la Tragicomedia La Celestina y era la misma que el Deponente tenia entregada al Comisario Dn. Joaquín de Ampuero, y corregida por un Sabio, quien le dixo se podia leer: por lo que no tubo reparo de darla a su hija menor."

(3) 5 diciembre 1791, de D. Francisco Domingo de Esnarrizaga: "De orden de el Señor D, Joaquín de Ampuero (...) he leydo y revisto un libro intitulado trajicomedia de Calisto y Melibea, correjida y enmendada por el Bachiller Dn. Fernando de Rojas natural de la Puebla de Montalban, y reconocido su contexto, hallo que a mas de ser la maior parte de ella, fomento o libertinaje, escuela de la lasciuia y seductiva de los sencillos corazones, contiene también como comprehendera quien atentamente contempla muchos períodos varias proposiciones escandalosas ofensivas de los piadosos oidos, y mal sonantes por o que y para fines que combengan, despues de un maduro examen y seria reuision, qual exige el asunto (..) doi el presente parezer (...)."

(4) 13 diciembre 1791, de Dr. Mello: "Por Comisión de Dn. Joaquín Ampuero (...) he visto el Libro intitulado tragi-Comedia de Calisto y Melibea, correjido y enmendado por el bachiller Fernando de Rojas (...) mi juicio es que el objeto á que mira este Drama sin duda que es piadoso, y Christiano, qual se deja conocer en el horror que pretende inspirar al vicio de la lasciuia con los desengaños y castigos que hace patentes a sus amadores. Pero tambien es evidente que los medios que establece el autor para este fin son inconexos (...) que solo sus terminos leidos por trascenam y de passo quanto mas acompañados de la accion en el teatro, bastan para ocasionar una cierta rina espiritual, segun aparece entre otras de las paginas 98-120-196-197. (...) Es verdad que introduce multitud de sentencias morales oportunas al caso pero van enlazadas de proposiciones, las mas indecentes, algunas mal sonantes, y no pocas sapientes haeresim, entre los quales es reparable la que parangona el gusto carnal con el deleite, que los Santos tienen el Cielo (..) como es de ver en la 
página 14 manuscrita (...) Por tanto soy de sentir, que aunque la lectura y representacion de este Drama fuere disimulable en el siglo 16 en que se escrivio atendida la sencillez del caracter español, en aquel tiempo, es oy manifiestamente peligrosa à las conciencias, supuesta la comun refinada malicia, y critica de la presente época, á no hacerse una general expurgacion de los terminos sucios è impropios con que se refieren los sucesos (..) y de los hipervoles impios, con que exagera la vehemencia del amor lascivo (...)."

\section{2}

Mateo Vicente Ximénez (secretario, Inquisión de Logroño), 3 octubre 1792.

(5) "Habiendo visto el Expediente formado en este Santo Oficio sobre la Tragicomedia de Celestina, ò Calixto y Melibea. Dixeron: Que sin embargo de estar mandada expurgar esta Tragicomedia en los pasajes que cita el Expurgatorio del año de 1747 , folio 1052 les parece que debe ser prohibida in totum (...)."

Fray Thomas Muñoz, Fray Luis García Benito (Madrid, convento de Nuestra Señora de la Victoria) 5 noviembre 1792.

(6) "De orden de V. I. hemos leydo un libro intitulado Tragicomedia de Calixto y Melibea (...) como asi mismo las copias de las censuras que se han dado a el (...). Esta obra (...) fue en otro tiempo examinada (...) y mandada expurgar en varios pasajes de las ediciones que de ella se hicieron en Sevilla por los años de 1539 y 1599, en Salamanca por los de 1558 y 1570, y en Alcalá por los de 1563,1569 \& 1591 y en Madrid por el de 1601, como resulta de nuestro Indice expurgatorio del año 1707, tom. 2, pág. 280, col. 1 y de el año 1747 pág. 1052, col. 1; y ultimamente del novisimo de 1790, pág. 40, col. 1 (...) No dudamos que esta obra tendria alguna aceptacion en sus primeros tiempos, lo que se convence con las repetidas ediciones que se hicieron de ella, y porque se creyo digna de ser traducida a otros idiomas (...) pero no obstante esta aceptacion, se vio tambien, que ella estaba sembrada de pasages obscenos, y de otras proposiciones injuriosas (...). y si no se prohibio del todo en aquel tiempo, tal vez seria o porque los censores anduviesen poco exactos, y demasiado indulgentes en sus censuras, o por la razon que ahora nos da el segundo censor, reducida a que "la lectura y representación del Drama podria ser disimulable en el siglo 16, 
en que se escrivio, atendida la sencillez del caracter español de aquel tiempo" (...) En comprobación de esto se remite este sabio a las páginas $98,120,196$ y 197, de esta edición y podia remitirse à otras muchas; $y$ añade con sobrado fundamento, que el Autor no se conforma con el fin que se propone: ¿Y como podemos decir que el se conformaba con este fin, quando toda la obra esta fomentando el espirito de la disolucion, y el de la lascivia, siendo una como Seccion practica, que en la mayor parte de sus páginas esta instruyendo en la seduccion de los corazones mas castos (...)? El primero de los dos sabios censores que por ahora han examinado esta obra se contenta con censurar en globo las doctrinas que creye dignas de calidad de oficio. El segundo las especifico en algun modo, $y$ falla que no es disimulable en estos tiempos (..). Pero como nosotros estemos persuadidos a que es imposible esta general expurgacion, por tanto somos de parecer que esta obra debe ser prohibida absolutamente porque sobre estara comprehendida en la regla $1 .^{a}$ de nuestro Indice expurgatorio, contiene muchas doctrinas respectivamente escandalosas, impias, ofensivas en los oydos piadosos, sapientes haeresim, e injuriosas a los Eclesiásticos seculares, y regulares en general, sin exceptuar a las dignidades mas altas, y sagradas.

Se encuentran estas seis censuras y prohibiciones reproducidas en $L$. Rubio, "Nuevas Consideraciones," en su Estudios sobre 'La Celestina' (Murcia: Universidad, 1985), 283-296.

\section{4}

Cassiano Pellicer, Tratado histórico sobre el origen y progreso de la comedia y del histrionismo en Espafla, Madrid, 1804.

"Entre los fines del mismo siglo XV y principio del XVI se compuso una comedia intitulada La Celestina, o Tragicomedia de Calixto y Melibea. Consta de dos autores: el primero fue Rodrigo Cota, natural de Toledo; y el segundo, o su continuador, el bachiller Fernando de Rojas, natural de la Puebla de Montalbán: se imprimió en $8 .^{\circ}$, está en prosa, y se divide en actos; pero no se compuso para representarse. En cuanto a la propiedad de los caracteres y del estilo es uno de los buenos libros que tiene la lengua castellana: pero su lección es muy peligrosa, y en el teatro causaria mayores daños. [A continuación cita a Juan de Valdés, quien "le celebra mucho"] y otro autor también antiguo hablando de esta comedia, dijo lo siguiente: ¿Quién duda sino que este librillo de Celestina es de los más 
discretos y sentenciosos que hay escritos?, pero es una flor de la cual saca miel el discreto, y ponzoña el malicioso: que, si le lee un hombre docto, mota las sentencias de todos los filósofos, dichas por la boca de aquella vieja y sus consortes, y queda avisado para saberse guardar de alcahuetas y rufianes; pero, si lo lee un ignorante, no entiende lo bueno, y solamente le queda en la memoria la traza que tuvo Calixto para entrar a hablar a Melibea, siendo el intento del libro bien diferente.

Con alusión a estos dos respetos dijo Cervantes que la Celestina era, en su opinión, libro divino, si encubriera más lo humano; y por lo que descubre de humano, o de obsceno, le ha prohibido el Santo Oficio." [A continuación, menciona a varias de las imitaciones de Celestina.]

F. Bouterwek. Geschichte der Poesie und Beredsamkeit seit dem Ende des driezehnten Jahrhunderts. Gotinga, 1804, III:129ss y 280. Nuestra cita viene de la traducción española de J. Gómez de la Cortina y N. Hugalde y Mollinedo, Historia de la literatura espantola, tomo I (Madrid: Impta. Eusebio Aguado, 1829), págs. 47-50. BNM 1-127051.

"Más célebre que las Eglogas de Juan de la Encina es el drama de Calisto y Melibea, que probablemente se empezó en tiempo de los Reyes Católicos, aunque algunos literatos remontan su principio hasta el reinado de don Juan II. Esta producción (comenzada según parece por el mismo Rodrigo de Cota) (...) aunque el continuador no fue tan feliz en sus pinturas como Rodrigo de Cota, penetró perfectamente el plan de éste (...) los autores solo atendieron á la utilidad moral en su plan, y á la verosimilitud en la egecucion. Propusiéronse dar a la juventud por medio de egemplos ... una lección que la librase de los artificios y seducciones de cierta clase de mugeres que, envegecidas en el vino, abrazan por recurso el oficio de corruptoras de las costumbres. (...) El laudable objecto de los autores la ha hecho apreciar en todos tiempos; pero no han faltado personas que sostengan (...) que sería mas prudente ocultar semejantes pinturas ... pues ... siempre reprobará el buen gusto semejantes escenas. (...) Es preciso confesar en alabanza del autor, que trata las escenas que pasan en casa de la seductora con toda la decencia posible; que pinta los caractéres viles, sobre todo el de Celestina, con energía y verdad ... y que en general brilla en toda la pieza la naturalidad y facilidad del diálogo, principalmente en el primero acto, que es del autor desconocido, y aventaja a los demas (...)." 
Los traductores (?) añaden en nota 100 (pág. 102): "En 1520 se publicó ya en Nieremberg una traducción alemana con el título de Huren Spiegel, espejo de putas."

Diego Clemencín. "Elogio de la reina católica Doña Isabel" (discurso leído en la Real Academia de la Historia, 31 de julio de 1807). Madrid: Impta. de Sancha, 1820.

Hablando de la literatura isabelina, Clemencín escribe en las págs. 404405 lo siguiente:

"... las farsas pastoriles del mismo Encina, que se representaron en casa de los duques de Alba (...), junto con la tragicomédia de la Celestina, producción de los ingénios toledanos Rodrigo Cota y Fernando de Rojas, eran los primeros rudimentos del arte dramático español, que continuaron cultivando Pedro de Lerma ... el maestro Fernán Pérez de Oliva y Bartholomé Torres Naharro, y que siguió adelantando con lentos pasos hasta que un siglo después el gran Lope lo llenó á un mismo tiempo de bellezas y de defectos."

1822

Fernando de Rojas. La Celestina. Madrid: León Amarita, 1822.

1825

Leandro Fernández de Moratín. Obras dramáticas y líricas de don ... París: Impta. Augusto Bobée, 1825; París: A. Coniam, 1826². Citamos de la segunda ed., tomo I, págs. xviii-xix.

Del esbozo de poética dramática que encabeza la obra:

"La comedia pinta a los hombres como son (...) Imitando, pues, tan de cerca a la naturaleza, no es de admirar que hablen en prosa los personajes cómicos; pero no se crea que esto pueda añadir facilidades a la composición (..) No es fácil hablar en prosa como hablaron Melibea y Areúsa, el Lazarillo, el pícaro Guzmán ... ." 
De una carta escrita el 23 de abril de 1831 "A Madame Emile de Girardin," reinando Fernando VII:

"Le théâtre espagnole moderne n'a pas l'originalité qu'on attend d'un peuple orgueilleusement naturel. (...) Il est rare de voir représenter aujourd'hui en Espagne une pièce que ne soit pas imitée du français. Je m'indigne de cette pauvreté d'invention: (...) Hier, cependant, on donnait Célestina [sic], comédie de l'ancien théâtre; elle m'a fort diverti! c'est un tableau de moeurs supérierement tracé. Une vielle femme passe por magicienne, mais elle a pour emploi réel l'habitude de fournir à tous les personnages de la pièce des occasions de se rencontrer (...) Un valet, furieux des tours que lui a joués la vielle, la dénonce à l'inquisition comme sorcière. Et cette malheueuse, por échapper au danger qui la menace, dément en un moment les ruses de sa vie entière. Au moment d'être arrêtée, elle dévoile les mystères qui avaient soutenu la curiosité du spectateur pendant les cinq actes de la pièce. Elle se défend (...) avex autant de chaleur qu'elle avait toujours mis d'adresse à se faire passer pour sorcière; et, sacrifiant à son salut, sa réputation diabolique si péniblement acquise, elle se tue à prouver à chaque personnage qu'elle a menti, et ce qu'il croyait merveilleux était tout naturel. (...) Une telle comédie ne pouvait être écrite qu'en Espagne.

Le jeu des acteurs espagnols est frappant de verité. (...) Pendant l'entr'acte, une jeune danseuse et un jeune homme sont venus représenter plutôt qu'exécuter un bolero."

Citado de Marqués de Custine. L'Espagne sous Ferdinand VII. París: $1838^{3}$, Vol. I: 279-281.

Fernando de Rojas. La Celestina. Madrid: León Amarita, 1835. Segunda edición corregida. 
Dear Colleagues:

I need input on a project I have put off for some time, but am about to undertake. It logically would involve any hispanist who reads fiction and non-fiction after 1499. That is, of course, the date of the appearance of the Comedia de Calisto y Melibea. Over the years I have been collecting references to the work, its characters, and its influence and reception wherever I stumbled upon them, or was directed to them by colleagues (this is where some of you have already been collaborators).

In 1985 I published a bibliography on Rojas/Celestina criticism from 1930-1985. It is out of print, and I am now expanding it to cover 1899-1999, in part from the continuing updates to the 1985 work that have been regularly appearing in Celestinesca. With luck, its appearance will coincide with the 500th anniversary of the Comedia. Ideally, a final version would take this research tool to 1822, the date of the first modern edition of Celestina (Madrid, León Amarita).

What is envisioned at the moment is a history of the reception of the work from 1499-1822, to include editions, continuations, imitations, translations, adaptations and all clear references to, commentary on, evaluation and uses made of the text, its characters and situations in this period. I will begin publishing this "work-in-progress" in Celestinesca, beginning with vol. 19, number 2 .

Your input will halp me guarantee that the final work will be as complete as possible. If you can send references - with or wothout exact bibliographical data, from out of your notes or your collective wide reading - to works containing such references, I will track them down, verify them, whatever is needed to incorporate these (a full context is planned) into the main work. I will, naturally, acknowledge all contributions. It can be this week, next month, next year ... the project is long term. And please feel free to mention this to colleagues who are not MLA members.

My thanks in advance for any future input, and best wishes,

May 1997 to August 1998:

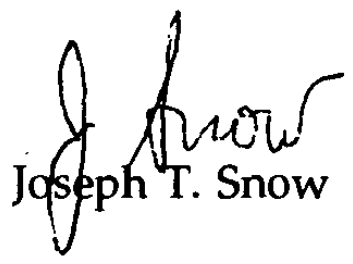

J.T. Snow

José Calvo 28, 3-D

28039 Madrid SPAIN 